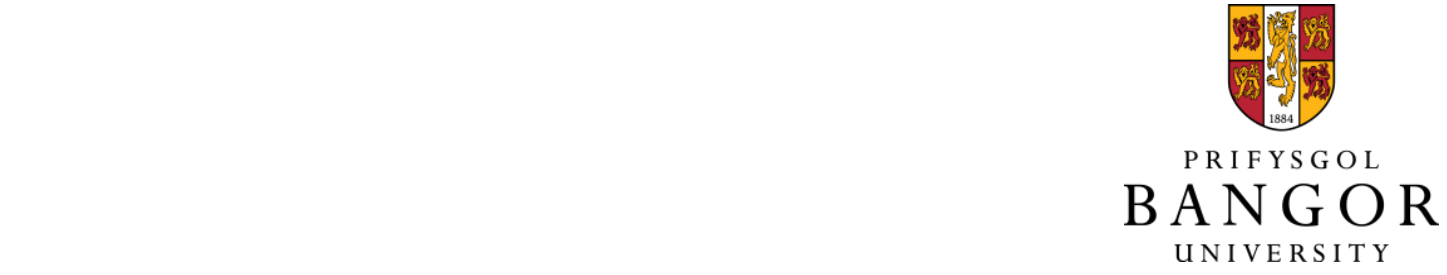

\title{
Use of Hydrologic Landscape Classification to Diagnose Streamflow
} Predictability in Oregon

Patil, S.D.; Wigington, P.J.; Leibowitz, S.G.; Comeleo, R.L.

Journal of the American Water Resources Association

DOI:

10.1111/jawr.12143

Published: 18/11/2013

Peer reviewed version

Cyswllt i'r cyhoeddiad / Link to publication

Dyfyniad o'r fersiwn a gyhoeddwyd / Citation for published version (APA):

Patil, S. D., Wigington, P. J., Leibowitz, S. G., \& Comeleo, R. L. (2013). Use of Hydrologic Landscape Classification to Diagnose Streamflow Predictability in Oregon. Journal of the American Water Resources Association, 50(3), 762-776. https://doi.org/10.1111/jawr.12143

Hawliau Cyffredinol / General rights

Copyright and moral rights for the publications made accessible in the public portal are retained by the authors and/or other copyright owners and it is a condition of accessing publications that users recognise and abide by the legal requirements associated with these rights. study or research.

download and print one copy of any publication from the public portal for the purpose of private

- You may not further distribute the material or use it for any profit-making activity or commercial gain

- You may freely distribute the URL identifying the publication in the public portal ?

Take down policy

Patil, Sopan D., Parker J. Wigington, Jr., Scott G. Leibowitz, and Randy L. Comeleo, 2013. Use of Hydrologic Landscape Classification to Diagnose Streamflow Predictability in Oregon. Journal of the American Water Resources Association (JAWRA) 50(3): 762-776. DOI: 10.1111/jawr.12143. @ 2013 American Water Resources Association

Take down policy

If you believe that this document breaches copyright please contact us providing details, and we will remove access to the work immediately and investigate your claim. 
NOTICE: This is the author's version of a work that was peer reviewed and accepted for publication in the Journal of the American Water Resources Association (JAWRA). Changes resulting from the publishing process, such as editing, corrections, structural formatting, and other quality control mechanisms may not be reflected in this document. A definitive version was subsequently published in JOURNAL OF THE AMERICAN WATER RESOURCES ASSOCIATION, VOL 50, DOI http://dx.doi.org/10.1111/jawr.12143

\title{
Use of Hydrologic Landscape Classification to Diagnose Streamflow Predictability in Oregon
}

\author{
Sopan Patil, Parker J. Wigington, Jr., Scott G. Leibowitz, Randy L. Comeleo*
}

Submission to:

Journal of the American Water Resources Association

* Respectively, ORISE Postdoctoral Researcher (Patil), Research Hydrologist, retired (Wigington), Research Ecologist (Leibowitz), Ecologist (Comeleo), U.S. Environmental Protection Agency, National Health and Environmental Effects Research Laboratory, Western Ecology Division, 200 SW 35 ${ }^{\text {th }}$ St. Corvallis, Oregon (Email/Patil: sopan.patil@gmail.com). 


\section{Abstract}

2 We implement a spatially lumped hydrologic model to predict daily streamflow at 88 catchments

3 within Oregon, USA and analyze its performance using the Oregon Hydrologic Landscape (OHL)

4 classification. OHL is used to identify the physio-climatic conditions that favor high (or low)

5 streamflow predictability. High prediction catchments (Nash-Sutcliffe efficiency of $\sqrt{Q}(\mathrm{NS})>$

$6 \quad$ 0.75) are mainly classified as rain dominated with very wet climate, low aquifer permeability, and

7 low to medium soil permeability. Most of them are located west of the Cascades Mountain Range.

8 Conversely, most low prediction catchments (NS < 0.6) are classified as snow dominated with

9 high aquifer permeability and medium to high soil permeability. They are mainly located in the

10 volcano-influenced High Cascades region. Using a subset of 36 catchments, we further test if class-

11 specific model parameters can be developed to predict at ungauged catchments. In most

12 catchments, OHL class-specific parameters provide predictions that are on par with individually

13 calibrated parameters (NS decline < 10\%). However, large NS declines are observed in OHL

14 classes where predictability is not high enough. Results suggest that higher uncertainty in rain-to-

15 snow transition of precipitation phase and external gains/losses of deep groundwater are major

16 factors for low prediction in Oregon. Moreover, regionalized estimation of model parameters is

17 more useful in regions where conditions favor good streamflow predictability.

19 KEY TERMS: surface water hydrology, simulation, streamflow, watersheds, rivers/streams. 


\section{Introduction}

Models in earth sciences, by definition, provide a simplified representation of real world processes and phenomena. For models in hydrology, the water balance concept is the fundamental

27 principle through which various fluxes of water are connected and organized within a catchment [Eagleson, 1978; Dooge, 1986; Kirkby, 2006]. Through this organizing principle, a variety of hydrologic models have been developed over the years and successfully implemented at numerous catchments across the world [Beven and Kirkby, 1979; Chiew and McMahon, 1994; Bergström, 1995; Edijatno et al., 1999; Perrin et al., 2003]. However, research has also shown that there are

32 limits to the physio-climatic conditions across which hydrologic models can provide good 33 streamflow predictions [Abdulla and Lettenmaier, 1997; Croke and Jakeman, 2001; Martinez and 34 Gupta, 2010; Li et al., 2012]. Specifically, for the prediction of daily streamflow over long periods, studies have shown that catchments in certain regions (e.g., with arid climate, or with high groundwater influence) are typically more difficult to predict [Ye et al., 1997; Hay and McCabe, 2002; Biftu and Gan, 2004; Clark et al., 2008; Fenicia et al., 2008; Fenicia et al., 2011]. Unfortunately, a complete understanding of why hydrologic models perform remarkably well in some regions, and why they fail to do so in other regions, has still not been achieved. main sources: (1) there is uncertainty (or error) in the meteorological inputs, (2) some key

42 hydrological processes unique to that catchment are either excluded or inappropriately represented

43 in the hydrologic model structure, and/or (3) there are unknown (and perhaps unmeasurable)

44 losses/gains of groundwater between the catchment and its surrounding region, which results in

45 the violation of the water balance principle. The first source can be addressed by choosing 46 meteorological forcing data of appropriate quality. A number of studies have shown that the 
47 quality of meteorological data used has a direct influence on the quality of modeled streamflow 48 predictions [Andréassian et al., 2001; Bárdossy and Das, 2008; McMillan et al., 2011]. Recent 49 studies such as Vaze et al. [2011] have further shown that better streamflow predictions are 50 obtained with the use of a gridded meteorological dataset than with a single meteorological gage 51 or a Theissen weighted average of multiple meteorological gages. The second source, hydrological

52 process representation, can be addressed to some extent by using the top-down approach to 53 hydrologic modeling [Klemeš, 1983; Sivapalan et al., 2003]. In the top-down approach, a chosen

54 model structure is first implemented at the catchment of interest and the model performance is 55 compared with observed streamflow data. If the model performance is unsatisfactory, process 56 components are either added to or removed from the model iteratively based on the available 57 geophysical catchment data and/or the modeler's judgment on which processes are more important 58 [Jothityangkoon et al., 2001; Farmer et al., 2003; Tekleab et al., 2011]. While this approach has 59 been shown to work at a few case-study catchments, the subjectivity involved in a modeler's 60 decisions and the ad hoc nature of available geophysical data in different parts of the world makes 61 this approach cumbersome and difficult to scale-up (i.e., apply consistently at a large number of 62 catchments on a regional/continental scale). The third source, losses/gains of groundwater, is the 63 most challenging to address due to our limited understanding of the conditions responsible for the 64 exports or imports of water outside a catchment boundary. It is also difficult to quantify these 65 losses and gains so that they can be explicitly accounted for in the water balance equations. While 66 there have been studies using coupled surface - ground water models at catchment scales 67 [Sophocleous and Perkins, 2000; Maxwell and Miller, 2005; Ireson et al., 2006], the borehole 68 water-table measurements required for the calibration of groundwater components are usually not 69 available in the majority of catchments. 
To overcome the restrictions in hydrologic characterization caused by limited data 71 availability, scientists have long suggested the need to develop a hydrologically-based

72 classification system for landscapes [Woods, 2002; McDonnell and Woods, 2004; Wagener et al.,

73 2007]. Such a classification system would ideally guide hydrologists in developing better

74 conceptual models of catchment function [McDonnell et al., 2007], and also narrow down the 75 causes for potential pitfalls in predictability despite the lack of detailed site measurements. 76 Although there have been numerous efforts over the years at developing a hydrologic classification 77 system [Mosley, 1981; Acreman and Sinclair, 1986; Wiltshire, 1986; Ogunkoya, 1988; Burn and 78 Goel, 2000], the study by Wolock et al. [2004] is perhaps the most comprehensive attempt at 79 hydrologic classification over large scales (they covered the entire United States, including Alaska 80 and Hawaii). This classification system was based on the Hydrologic Landscapes concept of 81 Winter [2001], and conceptualized that landscape units with similar soil, climate, and terrain 82 properties will have the same expected hydrologic behavior. Using this perceptual model, Wolock 83 et al. [2004] classified the entire United States into 20 broad Hydrologic Landscape Regions 84 (HLRs). Recently, Wigington et al. [2012] noted that, when viewed at the scale of an individual 85 state within the US, inconsistencies can be found in the HLR classification system, primarily due 86 to the coarse resolution of the data used by Wolock et al. [2004]. They suggested that a more 87 detailed approach is required at the state level and proposed the Oregon Hydrologic Landscapes 88 (OHL) classification, which uses a similar perceptual model as Wolock et al. [2004] but with higher 89 resolution geophysical data than what are available at the national scale.

90 In this paper, our goal is to demonstrate that a hydrologically based landscape classification 91 system can be effectively used to characterize the conditions at which a hydrologic model is more 92 likely to perform well; and also to understand why it does not perform well in certain 
93 environments. Furthermore, a classification system may provide a readily available perceptual

94 model of expected hydrologic behavior that can be compared against a mechanistic hydrologic

95 model to detect inconsistencies. Classification may also play an important role in the

96 characterization of hydrologic similarity among catchments and can help improve the

97 predictability at ungauged catchments. Although a classification system typically assumes that

98 similarity in physio-climatic properties translates into hydrologic similarity, a hydrologic model

99 can verify whether catchments belonging to the same classification group truly have similar

100 hydrologic behavior. As a specific example of this concept, we use a spatially lumped hydrologic

101 model called EXP-HYDRO [Patil and Stieglitz, 2012] to simulate daily streamflow at 88

102 catchments within the state of Oregon, USA and compare its simulation performance against the

103 OHL classification system of Wigington et al. [2012]. The mathematical structure of the EXP-

104 HYDRO model forms our a priori hypothesis of a catchment's expected hydrologic behavior. The

105 success or failure of this hypothesis (through good or bad prediction) at a catchment is then

106 analyzed with respect to the OHL classification system. Specifically, we seek to (1) identify the

107 physio-climatic properties that are more likely to be prevalent in high (and low) prediction

108 catchments, and (2) test if a common regionalized set of model parameters is applicable to all the

109 catchments that belong to the same classification unit. To our knowledge, there have been no

110 previous studies that have analyzed the geographic patterns of streamflow predictions obtained

111 through a hydrologic model within the context of a hydrologic classification framework. We

112 would also like to note here that the concepts presented in this paper are generic in nature and can

113 be readily implemented at different locations by using any other combination of hydrologic model

114 and/or hydrologic classification system. 
116 Data

117 We used the hydro-climatic data of 88 catchments located across the state of Oregon (see

118 Figure 1). These catchments were selected from two different U.S. Geological Survey databases, 119 viz., HCDN [Slack et al., 1993] and GAGES [Falcone et al., 2010], and are considered to be 120 "reference" condition catchments (suggesting minimal anthropogenic impact on flow regime) in 121 either of those databases. The drainage area of the catchments ranges from $8 \mathrm{~km}^{2}$ to $1730 \mathrm{~km}^{2}$, 122 with a median drainage area of $265 \mathrm{~km}^{2}$. The mean annual precipitation in the catchments ranges 123 from $530 \mathrm{~mm}$ to $3300 \mathrm{~mm}$, with a median value of $1700 \mathrm{~mm}$. The Cascade Mountain Range 124 traverses Oregon in the north - south direction, which creates a sharp contrast in climate among 125 catchments to the east and west of the mountain range. The western catchments are characterized 126 by a wet climate that is heavily influenced by the westerly winds of moisture-laden marine air 127 from the Pacific Ocean. On the other hand, the eastern catchments are characterized by a drier 128 climate (except at high elevations) mostly due to the rain-shadow effect created by the Cascade 129 Mountains. Detailed descriptions of the climatic, geologic, and topographic variations within the 130 state of Oregon can be found in Wigington et al. [2012].

131 The daily streamflow data was obtained from the USGS streamgages that are located at the 132 outlet of all the 88 catchments. For the streamflow data, we considered the time-span ranging 60 133 years from water year 1951 to 2010 . While every catchment did not have the data available for all 134 those years, all catchments had continuous streamflow measurements for at least 15 years within 135 this time-span. Daily precipitation and air temperature data were obtained from a gridded dataset 136 of observed climate developed by Maurer et al. [2002]. This dataset is gridded at 1/8 degree (about $13714 \mathrm{~km}$ ) spatial resolution and covers the entire continental United States. For each catchment, the 138 daily precipitation and air temperature time-series were obtained by taking an area-weighted 
139 average of the values from all the climate grids that are either fully or partially located within the 140 catchment.

\section{Methods}

\section{Hydrologic model}

144 The Exponential Bucket Hydrologic Model (EXP-HYDRO; see Figure 2) is a spatially 145 lumped hydrologic model [Patil and Stieglitz, 2012] that solves the following coupled water 146 balance equations of the catchment and snow accumulation bucket stores at each time step:

$$
\frac{d S}{d t}=P_{r}+M-E T-Q_{\text {bucket }}-Q_{\text {spill }}
$$

$$
\frac{d S_{s}}{d t}=P_{s}-M
$$

149 where, $S$ and $S_{s}$ are the amounts of water stored in the catchment and snow accumulation buckets,

150 respectively (unit: $\mathrm{mm}$ ), $P_{s}$ and $P_{r}$ are the daily snowfall and rainfall amounts, respectively (unit:

$151 \mathrm{~mm} /$ day), ET is the actual evapotranspiration (unit: $\mathrm{mm} /$ day), $Q_{b u c k e t}$ is the runoff generated from

152 the catchment bucket (unit: $\mathrm{mm} /$ day), $Q_{\text {spill }}$ is the capacity-excess runoff that occurs when the

153 catchment bucket is full (unit: $\mathrm{mm} /$ day), and $M$ is the snowmelt (unit: $\mathrm{mm} /$ day). The incoming

154 daily precipitation is classified as snowfall or rainfall based on the following condition:

155 If $T_{a}<T_{\min }$,

156

$$
\begin{aligned}
& P_{s}=P \\
& P_{r}=0
\end{aligned}
$$

157 Else, 


$$
\begin{aligned}
P_{s} & =0 \\
P_{r} & =P
\end{aligned}
$$

159 where, $T_{a}$ is actual daily air temperature (unit: ${ }^{\circ} \mathrm{C}$ ) and $T_{\min }$ is the air temperature (unit: ${ }^{\circ} \mathrm{C}$ ) below 160 which any precipitation in the catchment falls as snow (into the snow accumulation bucket).

161 Snowmelt $M$ from the snow accumulation bucket is modeled using a thermal degree-day model 162 as follows:

163 If $T_{a}>T_{\max }$,

$$
M=\min \left\{S_{s}, D_{f} \cdot\left(T_{a}-T_{\max }\right)\right\}
$$

165 Else,

$$
M=0
$$

167 where, $D_{f}$ is the thermal degree-day factor (unit: $\mathrm{mm} / \mathrm{day} /{ }^{\circ} \mathrm{C}$ ), and $T_{\max }$ is the air temperature 168 (unit: ${ }^{\circ} \mathrm{C}$ ) above which accumulated snow in the snow accumulation bucket begins to melt. 169 Evapotranspiration $E T$ is calculated as a fraction of the potential evapotranspiration ( $P E T$ ), and 170 depends on the amount of actual stored water $(S)$ in the catchment bucket relative to the bucket's 171 storage capacity $\left(S_{\max }\right)$ :

$$
E T=P E T \cdot\left(\frac{S}{S_{\max }}\right)
$$

173 PET (unit: $\mathrm{mm} /$ day) is calculated from the daily air temperature data using Hamon's formulation 174 [Hamon, 1963]. The runoff generated from the catchment bucket depends on the amount of water 175 stored in it and is calculated using a TOPMODEL [Beven and Kirkby, 1979] type equation:

176 If $S \leq S_{\max }$, 


$$
\begin{aligned}
& Q_{\text {bucket }}=Q_{\max } \cdot \exp \left(-f \cdot\left(S_{\max }-S\right)\right) \\
& Q_{\text {spill }}=0
\end{aligned}
$$

178 If $S>S_{\max }$,

$$
\begin{aligned}
& Q_{\text {bucket }}=Q_{\max } \\
& Q_{\text {spill }}=S-S_{\max }
\end{aligned}
$$

where, $Q_{\max }$ is the runoff produced (unit: $\mathrm{mm} /$ day) when the bucket storage reaches its maximum

181 capacity, and $f$ is the parameter controlling the storage-dependent exponential decline in bucket

182 generated runoff (unit: $1 / \mathrm{mm}$ ). It must be noted that although alternative forms of Equation 5a

183 have been proposed by some studies (e.g., linear, parabolic), the exponential version shown here

184 is the most widely used variant of the TOPMODEL equation [Ambroise et al., 1996; Li et al.,

185 2011]. Daily streamflow at the catchment outlet is the sum of $Q_{b u c k e t}$ and $Q_{s p i l l}$. The coupled 186 ordinary differential equations (Equation 1a and 1b) are solved simultaneously at each time step 187 using the $4^{\text {th }}$ order Runge-Kutta numerical scheme.

\section{Calibration of model parameters}

The EXP-HYDRO model consists of six free calibration parameters: $f, Q_{\max }, S_{\max }, D_{f}$,

$190 T_{\min }$, and $T_{\max }$. For each catchment, we calibrated these parameters with 50,000 Monte Carlo

191 simulations [Vaché and McDonnell, 2006; Patil and Stieglitz, 2012]. Table 1 shows the parameter

192 ranges used for generating the 50,000 uniformly distributed random samples of the six parameters.

193 Observed daily streamflow data from the first available 10 years for the catchment was chosen for 194 model optimization (calibration period), whereas the consecutive 5 years (years 11 to 15) were

195 chosen as the validation period. We used Nash Sutcliffe efficiency [Nash and Sutcliffe, 1970] of 196 square root values of daily streamflow as the objective function: 


$$
N S=1-\frac{\sum_{i=1}^{n}\left(\sqrt{Q_{o b s, i}}-\sqrt{Q_{\text {pred, }, i}}\right)^{2}}{\sum_{i=1}^{n}\left(\sqrt{Q_{o b s, i}}-\sqrt{\bar{Q}_{o b s}}\right)^{2}}
$$

198 where, $Q_{\text {pred,i }}$ and $Q_{o b s, i}$ are the predicted and the observed streamflow values on the $i^{\text {th }}$ day

199 respectively, $\bar{Q}_{o b s}$ is the mean of all the observed streamflow values and $n$ is the total number of 200 days in the time series. Nash Sutcliffe efficiency is the most widely used metric for calibration 201 and evaluation of hydrologic models that provide continuous simulation over a long period 202 [Legates and McCabe, 1999; Krause et al., 2005]. There are three commonly used variants of the 203 Nash Sutcliffe efficiency formula: untransformed $(Q)$, square root transformed $(\sqrt{Q})$, and $\log$ 204 transformed $(\log Q)$ [Oudin et al., 2006]. As an objective function, NS $(Q)$ has a tendency to 205 over-emphasize the matching of high flow values at the expense of low flows, whereas NS $(\log Q$

206 ) tends to do the opposite. NS ( $\sqrt{Q})$ is a balance between these two extremes and focuses on 207 matching the overall hydrograph, albeit at the expense of very high and very low flow values. 208 Since our objective in this study was to match the overall hydrologic dynamics of a catchment, we 209 used NS ( $\sqrt{Q}$ ) as the objective function (Equation 6, and referred to simply as NS henceforth).

210 The value of NS ranges from negative infinity to 1 , with NS $=1$ being a perfect fit between the 211 model and observed data. Out of the 50,000 parameter sets used for calibration at each catchment, 212 we selected a single parameter set that provided the maximum value of NS as the optimal 213 parameter set. While the uncertainty in parameter values due to equifinality (i.e., multiple 214 combinations of parameter values providing similar model performance) exists in most hydrologic 215 models [Beven and Freer, 2001], we have restricted our focus to characterizing the best 216 performance that is achievable with the EXP-HYDRO model at each catchment. 


\section{Oregon Hydrologic Landscapes (OHL) classification at catchment scale}

Wigington et al. [2012] have used a hydrologic landscape unit (HLU; referred to as assessment unit in their paper) as the fundamental area to which a classification code is assigned

220 based on its physio-climatic properties. Every HLU is either a first-order or an incremental sub-

221 catchment that consists of a stream reach and a contributing hillslope. The HLUs were delineated

222 within Oregon by using the following procedure: (1) extract the stream network from USGS

223 National Elevation Dataset's 30 m DEM using a $25 \mathrm{~km}^{2}$ minimum drainage area threshold for 224 channel initiation, and (2) divide the landscape into HLUs along the stream nodes. Wigington et 225 al. [2012] divided the state of Oregon into 5660 HLUs and classified the HLUs (using available 226 climatic and geophysical data) based on five categories: annual climate, seasonality of water 227 surplus, aquifer permeability, terrain, and soil permeability. The different classification codes 228 within each category are summarized in Table 2. Based on these codes, an individual HLU is 229 assigned a multi-letter OHL class. For instance, a HLU that is assigned an OHL class "VwLML" 230 has the following physio-climatic properties: very wet climate, winter seasonality of water surplus, 231 low aquifer permeability, mountainous terrain, and low soil permeability. The underlying 232 assumption is that the HLUs that have the same OHL class are expected to have similar hydrologic

233 behavior. Detailed information about the procedure for obtaining HLUs within Oregon and 234 development of the OHL classes can be found in Wigington et al. [2012].

235 A catchment typically consists of an aggregation of multiple HLUs (see Figure 3). 236 However, some small catchments can contain only a single first-order HLU. In fact, 37 out of the 23788 catchments in this study contain only one HLU. For the 51 catchments that contain multiple 238 HLUs, we defined their OHL catchment class by first considering each of the five physio-climatic 239 categories separately and then identifying the class within each category that covers the largest 
240 area within the catchment (see Supplementary Table). For the 37 catchments containing only one

241 HLU, the class associated with that HLU was assigned as the OHL catchment class. Detailed

242 information about the OHL classes for all 88 catchments is provided in the Supplementary Table.

244 Results

245 Figure 4a shows the box-and-whisker plot of NS values of all the 88 catchments for the 246 calibration and validation periods. The median NS values for calibration and validation period 247 were 0.78 and 0.75 respectively. NS values of catchments for the validation period varied across 248 a slightly larger range than those for the calibration period. Figure $4 \mathrm{~b}$ shows the 1:1 relationship 249 of NS values for the calibration and validation periods. Although the difference in model 250 performance between those two periods is low in most catchments, large deviations can be found 251 in a few catchments with low NS values.

252 Based on the NS value of streamflow calibration, we divided the 88 Oregon catchments 253 into three hydrologic predictability groups: Group 1 (high predictability; NS > 0.75), Group 2 254 (medium predictability; $0.75 \geq \mathrm{NS} \geq 0.6$ ), and Group 3 (low predictability; $0.6>\mathrm{NS}$ ). We followed 255 Martinez and Gupta [2010] to set NS > 0.75 as a condition for high predictability catchments and 256 Patil and Stieglitz [2012] to set NS < 0.6 as a condition for low predictability catchments. The 257 remaining catchments $(0.75 \geq \mathrm{NS} \geq 0.6)$ were then assigned into the medium predictability group.

258 Figure 5 shows the geographic distribution of catchments classified into the three predictability 259 groups. The Group 1 catchments (49 in total, 56\%) are predominantly located in the westernmost 260 part of the state. Most are along the Oregon Coast Range, followed by some catchments on the 261 western side of the Cascade Mountains (Western Cascades), and only three catchments are in the 262 eastern part of the state (east of the Cascade Mountains). The Group 2 catchments (14 in total, 
$26316 \%$ ) are mostly on the western side of the Cascade Mountains, but many of them are located 264 closer to the mountain range than the Group 1 catchments. Five Group 2 catchments are located 265 on the eastern side of the Cascade Mountains. The majority of Group 3 catchments (25 in total, $26628 \%$ ) are located on either side of, but in the close vicinity to, the Cascade Mountains. Almost all 267 the catchments that are nearest to the eastern side of the Cascade Mountains belong to Group 3. 268 These catchments contain the tributaries of the Deschutes River. A few Group 3 catchments are 269 also located in the eastern and northeastern parts of Oregon.

270 We next analyzed how the three hydrologic predictability groups relate to the OHL 271 classification at the catchment scale. Each of the five physio-climatic categories (annual climate, 272 seasonality, aquifer permeability, terrain, and soil permeability) were considered separately, and 273 we calculated the extent to which each class is represented in the high, medium, and low 274 predictability catchments (Groups 1 -3). Table 3 summarizes the presence of each physio-climatic 275 class within Group $1-3$ catchments. Below, we provide a brief description of the major trends in 276 each category.

277 For annual climate, the majority of catchments in all three predictability groups have either 278 a wet $(\mathrm{W})$ or a very wet (V) climate. This is not surprising since the geographic distribution of the 27988 catchments is heavily skewed towards the wetter western part of Oregon. Nonetheless, the 280 proportion of V climate class gradually decreases from Group 1 to Group 3 catchments, whereas 281 the proportions of drier climate classes (M and D) show the opposite trend. For the seasonality of 282 water surplus, a clear contrast is observed among the different predictability groups. As we move 283 from Group 1 to Group 3, the extent of winter (w) seasonality class decreases rapidly from 92\% 284 in Group 1 to $28 \%$ in Group 3. On the other hand, spring (s) seasonality class is present in only $2858 \%$ of the Group 1 catchments, but present in $68 \%$ of the Group 3 catchments. Only one catchment 
286 has a summer (u) seasonality class, and it belongs to Group 3. The aquifer permeability category 287 also shows a sharp contrast between Group 1 and Group 3 catchments. Low (L) aquifer 288 permeability is dominant among the Group 1 catchments $(84 \%)$, whereas high $(\mathrm{H})$ aquifer 289 permeability is dominant among the Group 3 catchments (56\%). The Group 2 catchments are 290 dominated by the $\mathrm{H}$ aquifer permeability class (50\%), followed by L (29\%) and M (21\%) classes.

291 The terrain category is not useful as an explanatory variable in this exercise because all 88 292 catchments have the mountain (M) terrain class. For soil permeability, the majority of catchments 293 in all three groups have either low (L) or medium (M) soil permeability. However, catchments 294 with high $(\mathrm{H})$ soil permeability are exclusive to Group 3.

The OHL classification hypothesizes that landscape units (or catchments) having the same 296 OHL class should have similar hydrologic behavior. We tested this hypothesis using the following 297 procedure: (1) group all the catchments that have the same OHL class; (2) using the grouped 298 catchments from step 1, calculate the average value of all six parameters of the EXP-HYDRO 299 model; (3) simulate the daily streamflow of all catchments within the group using average 300 parameters from step 2, and calculate the decline in NS value compared to that from individual 301 catchment calibration case. Only four OHL classes were available to test this procedure, since 302 other classes did not have sufficient number of catchments. These four classes are: VwLML (9 303 catchments), VwLMM (12 catchments), WwLML (6 catchments), and WwLMM (9 catchments). 304 Table 4 shows the range of optimal values of the EXP-HYDRO model parameters for catchments 305 among the four OHL classes, and also their coefficient of variation (CV) within each class. Out 306 of the 6 model parameters, $f$ consistently has the smallest value of $\mathrm{CV}$ in all four classes. This 307 indicates that the optimal value of $f$ varies the least for catchments within an individual OHL class. 308 Interestingly, the study by Patil and Stieglitz [2012] has shown that $f$ is also the most sensitive 
309 (and identifiable) parameter of the EXP-HYDRO model. Table 5 shows the decline in model

310 performance when using class averaged parameters compared to the individually calibrated

311 parameters. The average decline in model performance was the lowest for the VwLML class (1\%)

312 and the highest for the WwLMM class (13\%). Figure 6 shows the relationship between the NS

313 value of a catchment using calibrated parameter set and the \% decline in NS when the class-

314 assigned common parameter set is used (for the 36 catchments in four OHL classes). Catchments

315 with a high calibrated NS show the least performance decline, and the \% decline in NS has an

316 increasing trend with decreasing calibrated NS values. Of the 36 catchments considered in this

317 analysis, only 5 catchments showed a decline in model performance of greater than $10 \%$.

318 Remarkably, none of the 9 catchments in the VwLML class showed a model performance decline

319 above $4 \%$.

321 Discussion

322 Results show that distinct patterns of streamflow predictability are obtained by 323 implementing the EXP-HYDRO model within the state of Oregon (Figure 5). While studies have 324 shown that wet climate tends to be favorable for obtaining good model predictions at a catchment 325 [Abdulla and Lettenmaier, 1997; Parajka et al., 2005; Martinez and Gupta, 2010], our results 326 suggest that climate alone is insufficient to determine whether high or low predictability can be 327 expected at a certain place. About $72 \%$ of the Group 3 catchments (low predictability; NS $<0.6$ ) 328 are classified as having either a wet (W) or very wet (V) climate. Based on the dominant 329 classification within each of the OHL category (Table 3), we expect that a catchment in Oregon 330 belonging to either the VwLMM or VwLML class has the greatest likelihood of being a high 331 predictability catchment. In other words, a very wet climate, winter seasonality of water surplus, 
332 low aquifer permeability, mountainous terrain, and low to medium soil permeability is the most 333 favorable combination of physio-climatic properties for obtaining high simulation performance

334 with the EXP-HYDRO model. Conversely, the low prediction catchments in Oregon show a 335 propensity towards spring seasonality of water surplus, high aquifer permeability, and medium to 336 high soil permeability (see Table 3 ).

337 An important advantage of using the OHL classification system is that it reveals multiple 338 physio-climatic factors that can affect streamflow predictions and therefore provides clues into the 339 reasons for poor model behavior at a catchment. For instance, 14 out of the 25 Group 3 catchments 340 and 7 out of the 14 Group 2 catchments are classified as having high aquifer permeability. High 341 aquifer permeability in a catchment suggests a greater likelihood of having losses/gains with 342 external groundwater sources that are difficult to quantify. The majority of Group 2 and 3 343 catchments with high aquifer permeability are located in or near the region closest to the Cascade 344 Mountains (see Figure 5), which is commonly referred to as the High Cascades. The geology of 345 this region is heavily influenced by relatively recent volcanic eruptions and lava flows, which have 346 created complex patterns of groundwater flow [O'Connor and Grant, 2003; Jefferson et al., 2006;

347 Tague et al., 2008]. This is in sharp contrast with the Western Cascades region which is located 348 to the west of the High Cascades and consists of older, more weathered, and impermeable volcanic 349 bedrock [Mayer and Naman, 2011]. Tague and Grant [2004] compared the streamflow regimes 350 of catchments in the Western and High Cascades and showed that the above mentioned differences 351 in geology have a direct impact on hydrologic response within each region. Specifically, rivers in 352 the Western Cascades are runoff-dominated with fast recession rates and low summer baseflow, 353 whereas rivers in the High Cascades are groundwater-dominated with more uniform flows, slower 354 recession rates, and higher summer baseflow [Safeeq et al., 2013]. Wigington et al. [2012] 
355 illustrated the Metolius River as an example of a High Cascades catchment whose flow regime is 356 significantly influenced by external groundwater interaction. Therefore, streamflow modeling in 357 an environment such as the High Cascades is most likely to require an explicit representation of 358 the external groundwater gains/losses, but at the cost of additional input data that might not be 359 readily available in most places. The EXP-HYDRO model used in this paper does not explicitly 360 account for groundwater gains/losses outside of the catchment boundary. Manga [1997] 361 implemented an unconfined aquifer flow model, based on Boussinesq's equation for unsteady 362 subsurface flow, at four spring-dominated tributaries of the Deschutes River near the High 363 Cascades. Although the model provided good streamflow predictions, Manga [1997] used 364 streamflow measurements from a nearby runoff-dominated catchment as a proxy for external 365 recharge into the unconfined aquifer model. In the absence of a nearby "proxy" catchment, 366 estimation of aquifer recharge in such a model is likely to induce high uncertainty and reduce the 367 confidence in model predictions. Gannett and Lite [2004] coupled a groundwater flow model 368 (MODFLOW) with a streamflow routing model to simulate discharge at the Upper Deschutes 369 Basin. However, they used water-level measurements from 983 wells to calibrate the coupled 370 model. The availability of such data cannot always be guaranteed at a catchment.

371 Spring seasonality of water surplus is another dominant feature among the lower 372 predictability (Group 2 and 3) catchments. Spring seasonality indicates that the hydrologic regime 373 of a catchment is noticeably influenced by spring snowmelt [Wigington et al., 2012]. Our dataset 374 contains 28 catchments with spring seasonality, of which 24 (86\%) belonged to Group 2 and 3. 375 However, out of these 24 catchments, 15 catchments (63\%) have high aquifer permeability as a 376 dominant feature. This suggests that isolating the individual impact of either high aquifer 377 permeability or spring snowmelt on poor model prediction is not so straightforward for many 
378 catchments in Oregon. Figure 7 shows the relationship of NS with the inter-annual coefficient of 379 variation $(\mathrm{CV})$ of precipitation $(\mathrm{P})$ and air temperature $(\mathrm{T})$ (calculated from the 15 years used for 380 calibration and validation) of all our study catchments with NS $>0$. No significant trend exists in 381 the relationship between NS and the CV of $\mathrm{P}\left(\mathrm{r}^{2}=0.02\right.$, $\mathrm{p}$ value $\left.=0.22\right)$, which suggests that a 382 year-to-year change in the amount of precipitation does not have much effect on streamflow 383 predictability. On the other hand, a statistically significant trend exists in the relationship between 384 NS and the CV of $\mathrm{T}\left(\mathrm{r}^{2}=0.47\right.$, $\mathrm{p}$ value $\left.<0.01\right)$, such that the inter-annual variability in air 385 temperature increases with decrease in NS. This has important ramifications for the catchments 386 that are located in the rain/snow transition zones near the High Cascades, since small changes in 387 air temperature can have a significant impact on the amount of snow accumulation at a catchment 388 in a given year. Our results suggest that high year-to-year variability in air temperature increases 389 the uncertainty in the phase of precipitation (i.e., how much snow a catchment typically expects), 390 and is detrimental to streamflow predictability. Although the EXP-HYDRO model uses a simple 391 thermal degree-day model to represent the snow processes, it is not clear whether a more complex 392 snow model, that explicitly simulates the altitude effects [Blöschl et al., 1991; Corbari et al., 393 2009], sublimation [MacDonald et al., 2010], variable lapse rates [Nolin and Daly, 2006], and/or 394 ground temperature [Stieglitz et al., 2001], can lead to any improvements in the streamflow 395 prediction skills. It is important to note that such an increase in the complexity of a snow model 396 usually requires additional input data, which might not be available in many places.

397 Prediction of streamflow at ungauged catchments is an important factor that has long 398 motivated hydrologists towards the development of classification systems [Mosley, 1981; 399 McDonnell and Woods, 2004; Wagener et al., 2007]. In this study, we tested whether a class400 assigned common parameter set of the EXP-HYDRO model can provide simulation performance 
401 that is close enough to the performance obtained with individually calibrated parameters. While

402 this analysis was limited to only four OHL classes, our results showed that implementation of a 403 common parameter set for an entire OHL class provides near optimal (less than $10 \%$ deterioration)

404 performance in most catchments (31 out of 36; see Table 5). This suggests that, for the most part, 405 catchments within the same class tend to have similar hydrologic behavior, thereby providing an 406 independent validation of the OHL classification system. Parameter transfer based on physical 407 catchment similarity has generally yielded mixed results in the past, where some studies have 408 shown good performance at ungauged catchments [Parajka et al., 2005; Young, 2006], while 409 others have suggested that in certain cases, a mismatch exists between physical and hydrologic 410 similarity [Kokkonen et al., 2003; Oudin et al., 2010]. Of the four OHL classes, the WwLMM 411 class contains the most catchments with a high decline in NS (3 out of 9 catchments in that class 412 have $>10 \%$ NS decline). Interestingly, the average calibrated NS value of catchments is also the 413 lowest in the WwLMM class (avg. NS = 0.75). In comparison, the other three classes have higher 414 average calibrated NS $(\mathrm{VwLML}=0.90 ; \mathrm{VwLMM}=0.84 ; \mathrm{WwLML}=0.81)$. These findings are 415 suggestive of an inherent link between similarity among catchments, in terms of model parameters 416 and hydrologic landscape characteristics, and the hydrologic predictability of that catchment 417 group/type. If catchments within a particular class are highly predictable (e.g., VwLML), their 418 model parameters are more likely to be similar and therefore easily transferrable to an ungauged 419 catchment within the same class (see Table 4). On the other hand, physio-climatic similarity 420 among catchments (as characterized by OHL) is less useful if the model performance for that class 421 of catchments is not high enough to begin with, perhaps due to some hydrologic characteristics 422 (such as groundwater influence) that are difficult to incorporate into a regional classification 423 scheme. 


\section{Caveats}

We made several assumptions in our choice of the catchment data, classification scheme,

426 and the hydrologic model that can potentially influence the findings of this study. While Oregon

427 covers a large and diverse geographic area of the Pacific Northwest, the 88 catchments in this

428 study were not evenly distributed throughout the state, with the majority of them located in the

429 western part. This skew in the geographic distribution increased the number of catchments having

430 OHL classes that are more prevalent in western Oregon and decreased the number of catchments

431 having classes that are more typical of eastern Oregon, such as drier climate and spring or summer

432 seasonality. Another limitation was the lack of diversity in the OHL classes within our data.

433 Theoretically, there are 486 possible classes in the OHL classification system. Of these, 157

434 classes can be found in Oregon at the HLU level [Wigington et al., 2012]. However, at the

435 aggregated catchment level, only 19 unique OHL classes were manifested among the 88

436 catchments in this study (see Supplementary Table). Furthermore, the four most common OHL

437 classes (VwLML, VwLMM, WwLML, and WwLMM) that we considered for the analysis of

438 ungauged catchments were quite similar to each other, and prevented us from taking full advantage

439 of the high hydrologic diversity that exists within Oregon. The choice of hydrologic classification

440 scheme also had a major influence on our geographic interpretations of model predictability. For

441 instance, Wigington et al. [2012] used five types of physio-climatic data that they considered to be

442 relevant for hydrologic classification, and then made further subjective decisions on how many

443 classes can exist within each data type. Modifications in either of those decisions will change the

444 spatial distribution of landscape classes. The method that we used for aggregating the OHL classes

445 of individual HLUs to the catchment scale could also affect our results. We selected the landscape

446 class in each of the five categories that had maximum areal coverage within the catchment. 
447 However, this method is less likely to be effective if there is high internal heterogeneity in the 448 physio-climatic properties of the catchment. Lastly, the choice of input data and model structure 449 play an important role on the observed spatial patterns of model predictions. While we used high 450 quality gridded meteorological data [Maurer et al., 2002] as model inputs, estimates of rain and 451 snow tend to be poorer at high elevations. In terms of the model structure, we used a single bucket 452 spatially lumped model that has been tested over a large number of catchments within the 453 continental US [Patil and Stieglitz, 2012] and represents the hydrological processes that are

454 prevalent in most catchments. While the EXP-HYDRO model was used as a specific example for 455 the diagnosis of model behavior, the methods described in the paper can be readily used to analyze 456 the strengths and weaknesses of different types of hydrologic models.

\section{Concluding Remarks}

459 This study focused on testing whether a hydrologically based landscape classification 460 system can improve our understanding of why a hydrologic model performs remarkably well in 461 some regions, and why it fails to do so in other regions. Using the EXP-HYDRO model and OHL 462 classification as examples, we simulated daily streamflow in 88 catchments within Oregon, USA 463 and compared the model predictability with the OHL classes of the catchments. We further tested 464 whether class-specific model parameters can be developed and successfully implemented at 465 ungauged catchments with similar OHL class. The main contribution of this paper is in showing 466 that a hydrologic classification system is an efficient tool for analyzing a hydrologic model's 467 strengths and weaknesses across a large number of catchments, thereby making it easier to identify 468 and understand where the model weaknesses come from. Our results demonstrated that a 469 hydrologically-based landscape classification system like OHL [Wigington et al., 2012] can be 
470 effectively used to identify conditions that favor good streamflow predictability with a hydrologic 471 model like EXP-HYDRO and also to constrain the potential causes for poor predictability at a 472 catchment. This improved understanding of model success/failure can guide hydrologists during

473 the revision of model structures using a top-down approach. Within the state of Oregon, a very 474 wet climate, winter seasonality of water surplus, low aquifer permeability, mountainous terrain, 475 and low to medium soil permeability is the most favorable combination of physio-climatic 476 properties for high simulation performance with the EXP-HYDRO model. Results also showed 477 that the OHL class-specific common parameters provide model performance that is almost on par 478 with individually calibrated parameters in most catchments. However, performance deterioration 479 with the class-specific common parameters is likely to be greater if the predictability of that OHL 480 class is not high to begin with. This has important ramifications for estimating model parameters 481 at ungauged catchments. Specifically, regionalized estimation of model parameters is more likely 482 to be more useful in regions that have physio-climatic conditions that favor good hydrologic 483 predictability.

\section{Supporting Information}

486 Additional supporting information may be found in the online version of this article:

487 Supplementary Table S1: OHL class obtained for all 88 Oregon catchments.

\section{Acknowledgments}

490 We are thankful to C. Rhett Jackson, Bob Ozretich, and three anonymous reviewers for valuable 491 comments and suggestions that have greatly improved this paper. The first author was supported 492 by ORISE postdoctoral fellowship for the duration of this study. The information in this document 
has been funded entirely by the U.S. Environmental Protection Agency. This manuscript has been subjected to Agency review and has been approved for publication. Mention of trade names or commercial products does not constitute endorsement or recommendation for use.

\section{Literature Cited}

Abdulla, F. A., and D. P. Lettenmaier (1997), Development of regional parameter estimation equations for a macroscale hydrologic model, Journal of Hydrology, 197(1-4), 230-257, doi: 10.1016/s0022-1694(96)03262-3.

Acreman, M. C., and C. D. Sinclair (1986), Classification of drainage basins according to their physical characteristics; an application for flood frequency analysis in Scotland, Journal of Hydrology, 84(3-4), 365-380, doi: 10.1016/0022-1694(86)90134-4.

Ambroise, B., K. Beven, and J. Freer (1996), Toward a Generalization of the TOPMODEL Concepts: Topographic Indices of Hydrological Similarity, Water Resources Research, 32(7), 2135-2145, doi: 10.1029/95wr03716.

Andréassian, V., C. Perrin, C. Michel, I. Usart-Sanchez, and J. Lavabre (2001), Impact of imperfect rainfall knowledge on the efficiency and the parameters of watershed models, Journal of Hydrology, 250(1-4), 206-223, doi: http://dx.doi.org/10.1016/S00221694(01)00437-1.

Bárdossy, A., and T. Das (2008), Influence of rainfall observation network on model calibration and application, Hydrology and Earth System Sciences, 12(1), 77-89, doi: 10.5194/hess12-77-2008.

Bergström, S. (1995), The HBV model, in Computer models of watershed hydrology, edited by V. P. Singh, pp. 443-476, Water Resources Publications, Colorado.

Beven, K. J., and M. J. Kirkby (1979), A physically based, variable contributing area model of basin hydrology / Un modèle à base physique de zone d'appel variable de l'hydrologie du bassin versant, Hydrological Sciences Bulletin, 24(1), 43-69, doi: 10.1080/02626667909491834.

Beven, K. J., and J. Freer (2001), Equifinality, data assimilation, and uncertainty estimation in mechanistic modelling of complex environmental systems using the GLUE methodology, Journal of Hydrology, 249(1-4), 11-29, doi: 10.1016/s0022-1694(01)00421-8.

Biftu, G. F., and T. Y. Gan (2004), A semi-distributed, physics-based hydrologic model using remotely sensed and Digital Terrain Elevation Data for semi-arid catchments, International Journal of Remote Sensing, 25(20), 4351-4379, doi: 10.1080/01431160310001654374. 
Blöschl, G., R. Kirnbauer, and D. Gutknecht (1991), Distributed Snowmelt Simulations in an Alpine Catchment: 1. Model Evaluation on the Basis of Snow Cover Patterns, Water Resources Research, 27(12), 3171-3179, doi: 10.1029/91wr02250.

Burn, D. H., and N. K. Goel (2000), The formation of groups for regional flood frequency analysis, Hydrological Sciences Journal, 45(1), 97-112, doi: 10.1080/02626660009492308.

Chiew, F., and T. McMahon (1994), Application of the daily rainfall-runoff model MODHYDROLOG to 28 Australian catchments, Journal of Hydrology, 153(1-4), 383416, doi: 10.1016/0022-1694(94)90200-3.

Clark, M. P., A. G. Slater, D. E. Rupp, R. A. Woods, J. A. Vrugt, H. V. Gupta, T. Wagener, and L. E. Hay (2008), Framework for Understanding Structural Errors (FUSE): A modular framework to diagnose differences between hydrological models, Water Resources Research, 44, W00B02, doi: 10.1029/2007wr006735.

Corbari, C., G. Ravazzani, J. Martinelli, and M. Mancini (2009), Elevation based correction of snow coverage retrieved from satellite images to improve model calibration, Hydrology and Earth System Sciences, 13(5), 639-649, doi: 10.5194/hess-13-639-2009.

Croke, B. F. W., and A. J. Jakeman (2001), Predictions in catchment hydrology: an Australian perspective, Marine and Freshwater Research, 52(1), 65-79, doi: 10.1071/MF00045.

Dooge, J. C. I. (1986), Looking for hydrologic laws, Water Resources Research, 22(9S), 46S-58S, doi: 10.1029/WR022i09Sp0046S.

Eagleson, P. S. (1978), Climate, soil, and vegetation: 1. Introduction to water balance dynamics, Water Resources Research, 14(5), 705-712, doi: 10.1029/WR014i005p00705.

Edijatno, N. De Oliveira Nascimento, X. Yang, Z. Makhlouf, and C. Michel (1999), GR3J: a daily watershed model with three free parameters, Hydrological Sciences Journal, 44(2), 263277, doi: 10.1080/02626669909492221.

Falcone, J. A., D. M. Carlisle, D. M. Wolock, and M. R. Meador (2010), GAGES: A stream gage database for evaluating natural and altered flow conditions in the conterminous United States, Ecology, 91(2), 621-621, doi: 10.1890/09-0889.1.

Farmer, D., M. Sivapalan, and C. Jothityangkoon (2003), Climate, soil, and vegetation controls upon the variability of water balance in temperate and semiarid landscapes: Downward approach to water balance analysis, Water Resources Research, 39(2), 1035, doi: $10.1029 / 2001 \mathrm{wr} 000328$.

Fenicia, F., D. Kavetski, and H. H. G. Savenije (2011), Elements of a flexible approach for conceptual hydrological modeling: 1. Motivation and theoretical development, Water Resources Research, 47(11), W11510, doi: 10.1029/2010wr010174. 
Fenicia, F., H. H. G. Savenije, P. Matgen, and L. Pfister (2008), Understanding catchment behavior through stepwise model concept improvement, Water Resources Research, 44(1), W01402, doi: 10.1029/2006wr005563.

Gannett, M. W., and K. E. Lite (2004), Simulation of regional ground-water flow in the upper Deschutes Basin, Oregon, Water-Resources Investigations Report 03-4195, US Geological Survey.

Hamon, W. R. (1963), Computation of direct runoff amounts from storm rainfall, Int. Assoc. Sci. Hydrol. Publ, 63, 52-62, doi.

Hay, L. E., and G. J. McCabe (2002), Spatial variability in water-balance model performance in the conterminous United States, JAWRA Journal of the American Water Resources Association, 38(3), 847-860, doi: 10.1111/j.1752-1688.2002.tb01001.x.

Ireson, A., C. Makropoulos, and C. Maksimovic (2006), Water Resources Modelling under Data Scarcity: Coupling MIKE BASIN and ASM Groundwater Model, Water Resources Management, 20(4), 567-590, doi: 10.1007/s11269-006-3085-2.

Jefferson, A., G. Grant, and T. Rose (2006), Influence of volcanic history on groundwater patterns on the west slope of the Oregon High Cascades, Water Resources Research, 42(12), W12411, doi: 10.1029/2005wr004812.

Jothityangkoon, C., M. Sivapalan, and D. L. Farmer (2001), Process controls of water balance variability in a large semi-arid catchment: downward approach to hydrological model development, Journal of Hydrology, 254(1-4), 174-198, doi: 10.1016/s00221694(01)00496-6.

Kirkby, M. (2006), Organization and Process, in Encyclopedia of Hydrological Sciences, edited, John Wiley \& Sons, Ltd, doi: 10.1002/0470848944.hsa003.

Klemeš, V. (1983), Conceptualization and scale in hydrology, Journal of Hydrology, 65(1-3), 123, doi: 10.1016/0022-1694(83)90208-1.

Kokkonen, T. S., A. J. Jakeman, P. C. Young, and H. J. Koivusalo (2003), Predicting daily flows in ungauged catchments: model regionalization from catchment descriptors at the Coweeta Hydrologic Laboratory, North Carolina, Hydrological Processes, 17(11), 2219-2238, doi: 10.1002/hyp.1329.

Krause, P., D. P. Boyle, and F. Bäse (2005), Comparison of different efficiency criteria for hydrological model assessment, Adv. Geosci., 5, 89-97, doi: 10.5194/adgeo-5-89-2005.

Legates, D. R., and G. J. McCabe (1999), Evaluating the use of "goodness-of-fit" Measures in hydrologic and hydroclimatic model validation, Water Resources Research, 35(1), 233241, doi: 10.1029/1998wr900018. 
Li, H., M. Sivapalan, and F. Tian (2012), Comparative diagnostic analysis of runoff generation processes in Oklahoma DMIP2 basins: The Blue River and the Illinois River, Journal of Hydrology, 418-419(0), 90-109, doi: http://dx.doi.org/10.1016/j.jhydrol.2010.08.005.

Li, H., M. Huang, M. S. Wigmosta, Y. Ke, A. M. Coleman, L. R. Leung, A. Wang, and D. M. Ricciuto (2011), Evaluating runoff simulations from the Community Land Model 4.0 using observations from flux towers and a mountainous watershed, Journal of Geophysical Research: Atmospheres, 116(D24), D24120, doi: 10.1029/2011jd016276.

MacDonald, M. K., J. W. Pomeroy, and A. Pietroniro (2010), On the importance of sublimation to an alpine snow mass balance in the Canadian Rocky Mountains, Hydrology and Earth System Sciences, 14(7), 1401-1415, doi: 10.5194/hess-14-1401-2010.

Manga, M. (1997), A model for discharge in spring-dominated streams and implications for the transmissivity and recharge of quaternary volcanics in the Oregon Cascades, Water Resources Research, 33(8), 1813-1822, doi: 10.1029/97wr01339.

Martinez, G. F., and H. V. Gupta (2010), Toward improved identification of hydrological models: A diagnostic evaluation of the "abcd" monthly water balance model for the conterminous United States, Water Resources Research, 46(8), W08507, doi: 10.1029/2009wr008294.

Maurer, E. P., A. W. Wood, J. C. Adam, D. P. Lettenmaier, and B. Nijssen (2002), A Long-Term Hydrologically Based Dataset of Land Surface Fluxes and States for the Conterminous United States, Journal of Climate, 15(22), 3237-3251, doi: 10.1175/15200442(2002)015<3237:althbd>2.0.co;2.

Maxwell, R. M., and N. L. Miller (2005), Development of a Coupled Land Surface and Groundwater Model, Journal of Hydrometeorology, 6(3), 233-247, doi: 10.1175/jhm422.1.

Mayer, T. D., and S. W. Naman (2011), Streamflow Response to Climate as Influenced by Geology and Elevation, JAWRA Journal of the American Water Resources Association, 47(4), 724738, doi: 10.1111/j.1752-1688.2011.00537.x.

McDonnell, J. J., and R. Woods (2004), On the need for catchment classification, Journal of Hydrology, 299(1-2), 2-3, doi: 10.1016/j.jhydrol.2004.09.003.

McDonnell, J. J., M. Sivapalan, K. Vaché, S. Dunn, G. Grant, R. Haggerty, C. Hinz, R. Hooper, J. Kirchner, M. L. Roderick, J. Selker, and M. Weiler (2007), Moving beyond heterogeneity and process complexity: A new vision for watershed hydrology, Water Resources Research, 43(7), W07301, doi: 10.1029/2006wr005467.

McMillan, H., B. Jackson, M. Clark, D. Kavetski, and R. Woods (2011), Rainfall uncertainty in hydrological modelling: An evaluation of multiplicative error models, Journal of Hydrology, 400(1-2), 83-94, doi: http://dx.doi.org/10.1016/j.jhydrol.2011.01.026.

Mosley, M. P. (1981), Delimitation of New Zealand hydrologic regions, Journal of Hydrology, 49(1-2), 173-192, doi: 10.1016/0022-1694(81)90211-0. 
Nash, J. E., and J. V. Sutcliffe (1970), River flow forecasting through conceptual models part I A discussion of principles, Journal of Hydrology, 10(3), 282-290, doi: 10.1016/00221694(70)90255-6.

Nolin, A. W., and C. Daly (2006), Mapping “At Risk” Snow in the Pacific Northwest, Journal of Hydrometeorology, 7(5), 1164-1171, doi: 10.1175/jhm543.1.

O'Connor, J. E., and G. E. Grant (2003), A Peculiar River: Geology, Geomorphology, and Hydrology of the Deschutes River, Oregon, 219 pp., AGU, Washington, DC.

Ogunkoya, O. O. (1988), Towards a delimitation of southwestern Nigeria into hydrological regions, Journal of Hydrology, 99(1-2), 165-177, doi: 10.1016/0022-1694(88)90085-6.

Oudin, L., A. Kay, V. Andréassian, and C. Perrin (2010), Are seemingly physically similar catchments truly hydrologically similar?, Water Resources Research, 46(11), W11558, doi: $10.1029 / 2009 w r 008887$.

Oudin, L., V. Andréassian, T. Mathevet, C. Perrin, and C. Michel (2006), Dynamic averaging of rainfall-runoff model simulations from complementary model parameterizations, Water Resources Research, 42(7), W07410, doi: 10.1029/2005wr004636.

Parajka, J., R. Merz, and G. Blöschl (2005), A comparison of regionalisation methods for catchment model parameters, Hydrology and Earth System Sciences, 9(3), 157-171, doi: 10.5194/hess-9-157-2005.

Patil, S., and M. Stieglitz (2012), Modelling daily streamflow at ungauged catchments: what information is necessary?, Hydrological Processes, doi: 10.1002/hyp.9660.

Perrin, C., C. Michel, and V. Andréassian (2003), Improvement of a parsimonious model for streamflow simulation, Journal of Hydrology, 279(1-4), 275-289, doi: 10.1016/s00221694(03)00225-7.

Safeeq, M., G. E. Grant, S. L. Lewis, and C. L. Tague (2013), Coupling snowpack and groundwater dynamics to interpret historical streamflow trends in the western United States, Hydrological Processes, 27(5), 655-668, doi: 10.1002/hyp.9628.

Sivapalan, M., G. Blöschl, L. Zhang, and R. Vertessy (2003), Downward approach to hydrological prediction, Hydrological Processes, 17(11), 2101-2111, doi: 10.1002/hyp.1425.

Slack, J. R., A. Lumb, and J. M. Landwehr (1993), Hydro-Climatic Data Network (HCDN) Streamflow Data Set, 1874-1988: USGS Water-Resources Investigations Report 93-4076, U.S. Geological Survey, Reston, VA.

Sophocleous, M., and S. P. Perkins (2000), Methodology and application of combined watershed and ground-water models in Kansas, Journal of Hydrology, 236(3-4), 185-201, doi: 10.1016/s0022-1694(00)00293-6. 
664

Stieglitz, M., A. Ducharne, R. Koster, and M. Suarez (2001), The Impact of Detailed Snow Physics on the Simulation of Snow Cover and Subsurface Thermodynamics at Continental Scales, Journal of Hydrometeorology, 2(3), 228-242, doi: 10.1175/15257541(2001)002<0228:tiodsp >2.0.co;2.

Tague, C., and G. E. Grant (2004), A geological framework for interpreting the low-flow regimes of Cascade streams, Willamette River Basin, Oregon, Water Resources Research, 40(4), W04303, doi: 10.1029/2003wr002629.

Tague, C., G. Grant, M. Farrell, J. Choate, and A. Jefferson (2008), Deep groundwater mediates streamflow response to climate warming in the Oregon Cascades, Climatic Change, 86(1), 189-210, doi: 10.1007/s10584-007-9294-8.

Tekleab, S., S. Uhlenbrook, Y. Mohamed, H. H. G. Savenije, M. Temesgen, and J. Wenninger (2011), Water balance modeling of Upper Blue Nile catchments using a top-down approach, Hydrology and Earth System Sciences, 15(7), 2179-2193, doi: 10.5194/hess-152179-2011.

Vaché, K. B., and J. J. McDonnell (2006), A process-based rejectionist framework for evaluating catchment runoff model structure, Water Resources Research, 42(2), W02409, doi: $10.1029 / 2005 \mathrm{wr} 004247$.

Vaze, J., D. A. Post, F. H. S. Chiew, J. M. Perraud, J. Teng, and N. R. Viney (2011), Conceptual Rainfall-Runoff Model Performance with Different Spatial Rainfall Inputs, Journal of Hydrometeorology, 12(5), 1100-1112, doi: 10.1175/2011jhm1340.1.

Wagener, T., M. Sivapalan, P. Troch, and R. Woods (2007), Catchment Classification and Hydrologic Similarity, Geography Compass, 1(4), 901-931, doi: 10.1111/j.17498198.2007.00039.x.

Wigington, P. J., S. G. Leibowitz, R. L. Comeleo, and J. L. Ebersole (2012), Oregon Hydrologic Landscapes: A Classification Framework, JAWRA Journal of the American Water Resources Association, 49(1), 163-182, doi: 10.1111/jawr.12009.

Wiltshire, S. E. (1986), Identification of homogeneous regions for flood frequency analysis, Journal of Hydrology, 84(3-4), 287-302, doi: 10.1016/0022-1694(86)90128-9.

Winter, T. C. (2001), The Concept of Hydrologic Landscapes, JAWRA Journal of the American Water Resources Association, 37(2), 335-349, doi: 10.1111/j.1752-1688.2001.tb00973.x.

Wolock, D. M., T. C. Winter, and G. McMahon (2004), Delineation and Evaluation of HydrologicLandscape Regions in the United States Using Geographic Information System Tools and Multivariate Statistical Analyses, Environmental Management, 34(0), S71-S88, doi: 10.1007/s00267-003-5077-9.

Woods, R. (2002), Seeing catchments with new eyes, Hydrological Processes, 16(5), 1111-1113, doi: 10.1002/hyp.539. 
Ye, W., B. C. Bates, N. R. Viney, M. Sivapalan, and A. J. Jakeman (1997), Performance of conceptual rainfall-runoff models in low-yielding ephemeral catchments, Water Resources Research, 33(1), 153-166, doi: 10.1029/96wr02840.

Young, A. R. (2006), Stream flow simulation within UK ungauged catchments using a daily rainfall-runoff model, Journal of Hydrology, 320(1-2), 155-172, doi: 10.1016/j.jhydrol.2005.07.017.

706

707 


\section{Tables}

Table 1: Parameter ranges for calibration of EXP-HYDRO model.

\begin{tabular}{clccc}
\hline Parameter & \multicolumn{1}{c}{ Description } & Units & Lower Limit & Upper Limit \\
\hline$f$ & Rate of decline in subsurface runoff & $1 / \mathrm{mm}$ & 0.0 & 0.1 \\
$S_{\max }$ & Maximum storage of the catchment bucket & $\mathrm{mm}$ & 100.0 & 1500.0 \\
$Q_{\max }$ & Maximum subsurface runoff at full bucket & $\mathrm{mm} / \mathrm{day}$ & 10.0 & 50.0 \\
$D_{f}$ & Degree-day factor, i.e., rate of snowmelt & $\mathrm{mm} / \mathrm{day} /{ }^{\circ} \mathrm{C}$ & 0.0 & 5.0 \\
$T_{\max }$ & Temperature above which snow starts melting & ${ }^{\circ} \mathrm{C}$ & 0.0 & 4.0 \\
$T_{\min }$ & Temperature below which precipitation is snow & ${ }^{\circ} \mathrm{C}$ & -3.0 & 0.0 \\
\hline
\end{tabular}


Table 2: OHL classification codes for the five physio-climatic categories (Wigington et al. [2012]).

\begin{tabular}{ll}
\hline \multicolumn{1}{c}{ Category } & \multicolumn{1}{c}{ Classification code } \\
\hline Annual Climate & $\mathbf{V}=$ very wet, $\mathbf{W}=$ wet, $\mathbf{M}=$ moist, $\mathbf{D}=$ dry, $\mathbf{S}=$ semi-arid, $\mathbf{A}=$ arid \\
Seasonality of water surplus & $\mathbf{w}=$ winter, $\mathbf{s}=$ spring, $\mathbf{u}=$ summer \\
Aquifer permeability & $\mathbf{L}=$ low, $\mathbf{M}=$ medium, $\mathbf{H}=$ high \\
Terrain & $\mathbf{F}=$ flat, $\mathbf{T}=$ transitional, $\mathbf{M}=$ mountainous \\
Soil permeability & $\mathbf{L}=$ low, $\mathbf{M}=$ medium, $\mathbf{H}=$ high \\
\hline
\end{tabular}


Table 3: Distribution of OHL classes among the three predictability groups. Horizontal values add up to $100 \%$. Number of catchments in Group $1=49$, Group $2=14$, and Group $3=25$.

\begin{tabular}{|c|c|c|c|c|c|c|}
\hline \multicolumn{2}{|l|}{ Category } & \multicolumn{5}{|c|}{$\%$ presence of OHL class } \\
\hline Climate & $\mathbf{V}$ & $\mathbf{W}$ & $\mathbf{M}$ & D & $\mathbf{S}$ & $\mathbf{A}$ \\
\hline Group $1(0.75<\mathrm{NS})$ & 63 & 33 & 2 & 2 & - & - \\
\hline Group $2(0.6<\mathrm{NS}<0.75)$ & 57 & 21 & 14 & 7 & - & - \\
\hline Group 3 (NS < 0.6) & 24 & 48 & 16 & 12 & - & - \\
\hline Seasonality of water surplus & $\mathbf{w}$ & $\mathbf{s}$ & $\mathbf{u}$ & & & \\
\hline Group $1(0.75<\mathrm{NS})$ & 92 & 8 & - & & & \\
\hline Group $2(0.6<\mathrm{NS}<0.75)$ & 50 & 50 & - & & & \\
\hline Group 3 (NS < 0.6) & 28 & 68 & 4 & & & \\
\hline Aquifer permeability & $\mathbf{L}$ & $\mathbf{M}$ & $\mathbf{H}$ & & & \\
\hline Group $1(0.75<\mathrm{NS})$ & 84 & 4 & 12 & & & \\
\hline Group $2(0.6<\mathrm{NS}<0.75)$ & 29 & 21 & 50 & & & \\
\hline Group 3 (NS < 0.6) & 28 & 16 & 56 & & & \\
\hline Terrain & $\mathbf{F}$ & $\mathbf{T}$ & $\mathbf{M}$ & & & \\
\hline Group $1(0.75<\mathrm{NS})$ & - & - & 100 & & & \\
\hline Group $2(0.6<\mathrm{NS}<0.75)$ & - & - & 100 & & & \\
\hline Group 3 (NS < 0.6) & - & - & 100 & & & \\
\hline Soil permeability & $\mathbf{L}$ & $\mathbf{M}$ & $\mathbf{H}$ & & & \\
\hline Group $1(0.75<\mathrm{NS})$ & 39 & 61 & - & & & \\
\hline Group $2(0.6<\mathrm{NS}<0.75)$ & 21 & 79 & - & & & \\
\hline Group 3 (NS < 0.6) & 12 & 48 & 40 & & & \\
\hline
\end{tabular}


709 Table 4: Range of the calibrated parameter values of EXP-HYDRO model among catchments belonging to 710 each of the four OHL classes shown in Table 5. Numbers shown in parentheses are the coefficient of 711 variation of each parameter within a given $\mathrm{OHL}$ class.

\begin{tabular}{|c|c|c|c|c|c|c|}
\hline OHL Class & $\begin{array}{c}f \\
(1 / \mathrm{mm})\end{array}$ & $\begin{array}{c}S_{\max } \\
(\mathrm{mm})\end{array}$ & $\underset{\text { (mm/day) }}{Q_{\max }}$ & $\begin{array}{c}D_{f} \\
\left(\mathrm{~mm} / \text { day } /{ }^{\circ} \mathrm{C}\right)\end{array}$ & $\begin{array}{l}T_{\min } \\
\left({ }^{\circ} \mathrm{C}\right)\end{array}$ & $\begin{array}{l}T_{\max } \\
\left({ }^{\circ} \mathrm{C}\right)\end{array}$ \\
\hline VwLML & $\begin{array}{c}0.011 \text { to } 0.018 \\
\quad(0.15)\end{array}$ & $\begin{array}{c}456 \text { to } 847 \\
(0.22)\end{array}$ & $\begin{array}{c}101 \text { to } 990 \\
(0.61)\end{array}$ & $\begin{array}{c}1.08 \text { to } 4.98 \\
(0.31)\end{array}$ & $\begin{array}{c}-2.97 \text { to }-0.33 \\
(0.50)\end{array}$ & $\begin{array}{l}0.01 \text { to } 3.17 \\
\quad(1.01)\end{array}$ \\
\hline VwLMM & $\begin{array}{c}0.016 \text { to } 0.031 \\
(0.21)\end{array}$ & $\begin{array}{l}220 \text { to } 780 \\
(0.38)\end{array}$ & $\begin{array}{c}105 \text { to } 932 \\
(0.81)\end{array}$ & $\begin{array}{l}0.04 \text { to } 4.73 \\
(0.60)\end{array}$ & $\begin{array}{c}-2.95 \text { to }-0.76 \\
(0.48)\end{array}$ & $\begin{array}{c}0.66 \text { to } 3.99 \\
(0.57)\end{array}$ \\
\hline WwLML & $\begin{array}{c}0.017 \text { to } 0.031 \\
(0.25)\end{array}$ & $\begin{array}{c}346 \text { to } 596 \\
(0.20)\end{array}$ & $\begin{array}{c}108 \text { to } 774 \\
(0.76)\end{array}$ & $\begin{array}{l}0.37 \text { to } 4.54 \\
\quad(0.81)\end{array}$ & $\begin{array}{c}-1.32 \text { to }-0.34 \\
(0.42)\end{array}$ & $\begin{array}{c}1.25 \text { to } 3.84 \\
(0.29)\end{array}$ \\
\hline WwLMM & $\begin{array}{c}0.012 \text { to } 0.030 \\
(0.28)\end{array}$ & $\begin{array}{c}317 \text { to } \\
1497 \\
(0.58)\end{array}$ & $\begin{array}{c}103 \text { to } 989 \\
(0.77)\end{array}$ & $\begin{array}{l}0.00 \text { to } 3.16 \\
(1.84)\end{array}$ & $\begin{array}{c}-2.07 \text { to }-0.01 \\
(0.60)\end{array}$ & $\begin{array}{c}1.14 \text { to } 3.98 \\
(0.32)\end{array}$ \\
\hline
\end{tabular}


712 Table 5: Comparison of model performance in 36 catchments when using calibrated vs. OHL class-specific

713 average parameters. Bold values indicates catchments with $>\mathbf{1 0 \%}$ model performance decline.

\begin{tabular}{|c|c|c|c|c|}
\hline $\begin{array}{l}\text { OHL } \\
\text { Class }\end{array}$ & $\begin{array}{c}\text { USGS } \\
\text { Station no. }\end{array}$ & $\begin{array}{c}\text { NS } \\
\text { (calibration) }\end{array}$ & $\begin{array}{c}\mathrm{NS} \\
\text { (average parameters) }\end{array}$ & $\begin{array}{l}\% \text { decline in } \\
\text { NS }\end{array}$ \\
\hline \multirow{9}{*}{ VwLML } & 14189500 & 0.925 & 0.922 & 0.33 \\
\hline & 14193000 & 0.922 & 0.907 & 1.67 \\
\hline & 14194300 & 0.888 & 0.860 & 3.14 \\
\hline & 14197000 & 0.917 & 0.910 & 0.77 \\
\hline & 14301500 & 0.898 & 0.887 & 1.20 \\
\hline & 14303200 & 0.833 & 0.821 & 1.41 \\
\hline & 14303600 & 0.935 & 0.934 & 0.10 \\
\hline & 14305500 & 0.947 & 0.946 & 0.06 \\
\hline & 14306100 & 0.873 & 0.871 & 0.24 \\
\hline \multirow{12}{*}{ VwLMM } & 14141500 & 0.795 & 0.709 & 10.87 \\
\hline & 14150300 & 0.853 & 0.851 & 0.18 \\
\hline & 14161100 & 0.788 & 0.727 & 7.79 \\
\hline & 14182500 & 0.804 & 0.768 & 4.44 \\
\hline & 14185000 & 0.832 & 0.797 & 4.17 \\
\hline & 14185900 & 0.780 & 0.744 & 4.64 \\
\hline & 14187000 & 0.863 & 0.855 & 0.98 \\
\hline & 14198500 & 0.829 & 0.784 & 5.48 \\
\hline & 14306340 & 0.857 & 0.849 & 0.90 \\
\hline & 14306400 & 0.909 & 0.884 & 2.75 \\
\hline & 14324500 & 0.882 & 0.857 & 2.84 \\
\hline & 14325000 & 0.841 & 0.819 & 2.59 \\
\hline \multirow{6}{*}{ WwLML } & 14152500 & 0.798 & 0.784 & 1.82 \\
\hline & 14156500 & 0.799 & 0.783 & 2.01 \\
\hline & 14166500 & 0.899 & 0.785 & 12.66 \\
\hline & 14337800 & 0.825 & 0.794 & 3.79 \\
\hline & 14337870 & 0.687 & 0.633 & 7.88 \\
\hline & 14338000 & 0.834 & 0.806 & 3.41 \\
\hline \multirow{9}{*}{ WwLMM } & 14144900 & 0.598 & 0.216 & 63.94 \\
\hline & 14150800 & 0.811 & 0.792 & 2.31 \\
\hline & 14307700 & 0.755 & 0.700 & 7.26 \\
\hline & 14308000 & 0.839 & 0.808 & 3.73 \\
\hline & 14308990 & 0.569 & 0.498 & 12.54 \\
\hline & 14309500 & 0.790 & 0.767 & 2.86 \\
\hline & 14316700 & 0.848 & 0.804 & 5.17 \\
\hline & 14318000 & 0.766 & 0.722 & 5.70 \\
\hline & 14371500 & 0.845 & 0.722 & 14.52 \\
\hline
\end{tabular}




\section{Figures}

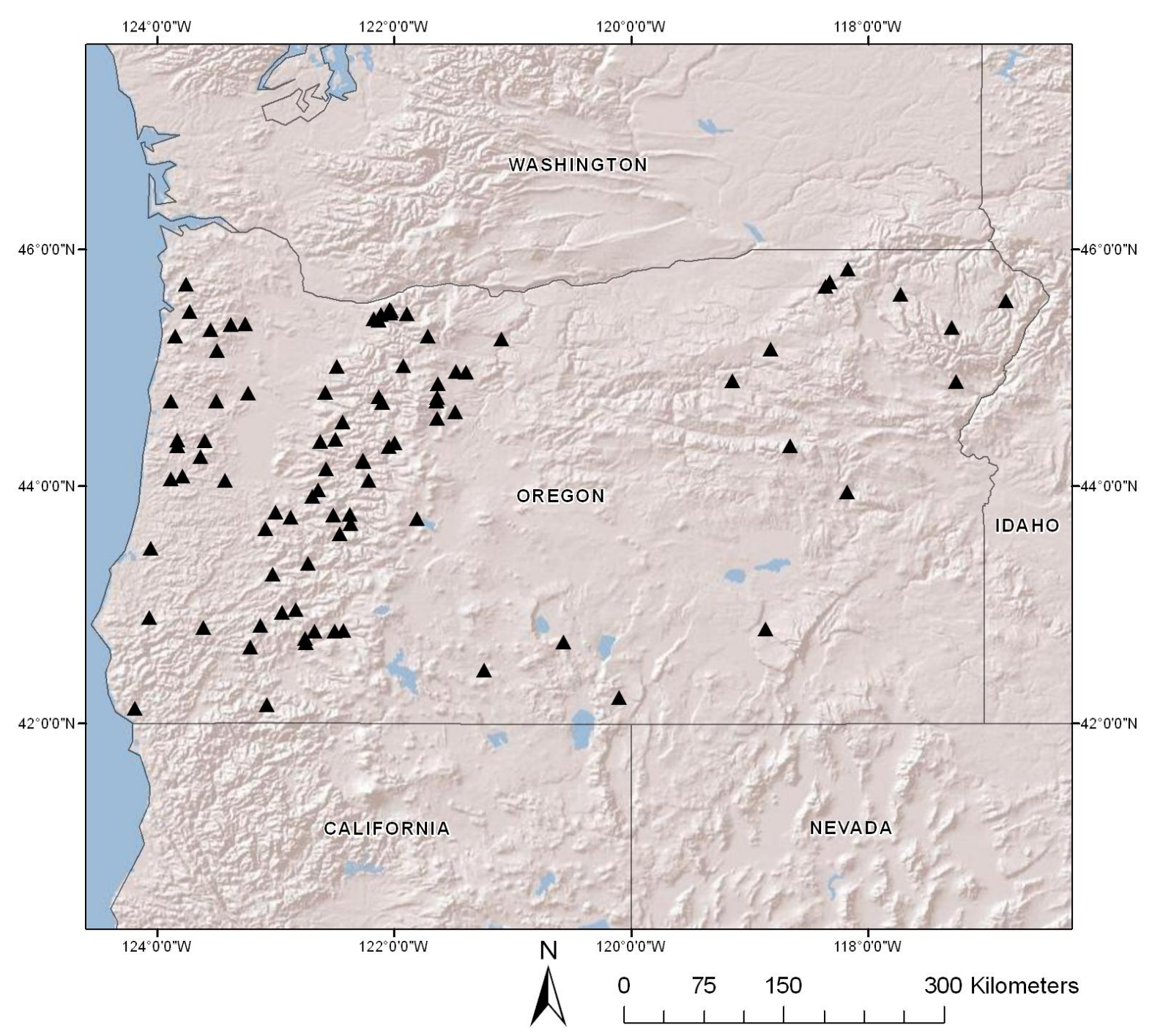

Figure 1: Location of the 88 catchment outlets within Oregon. Black triangles are the locations of catchment outlets. Map projected in WGS 1984 co-ordinate system. 


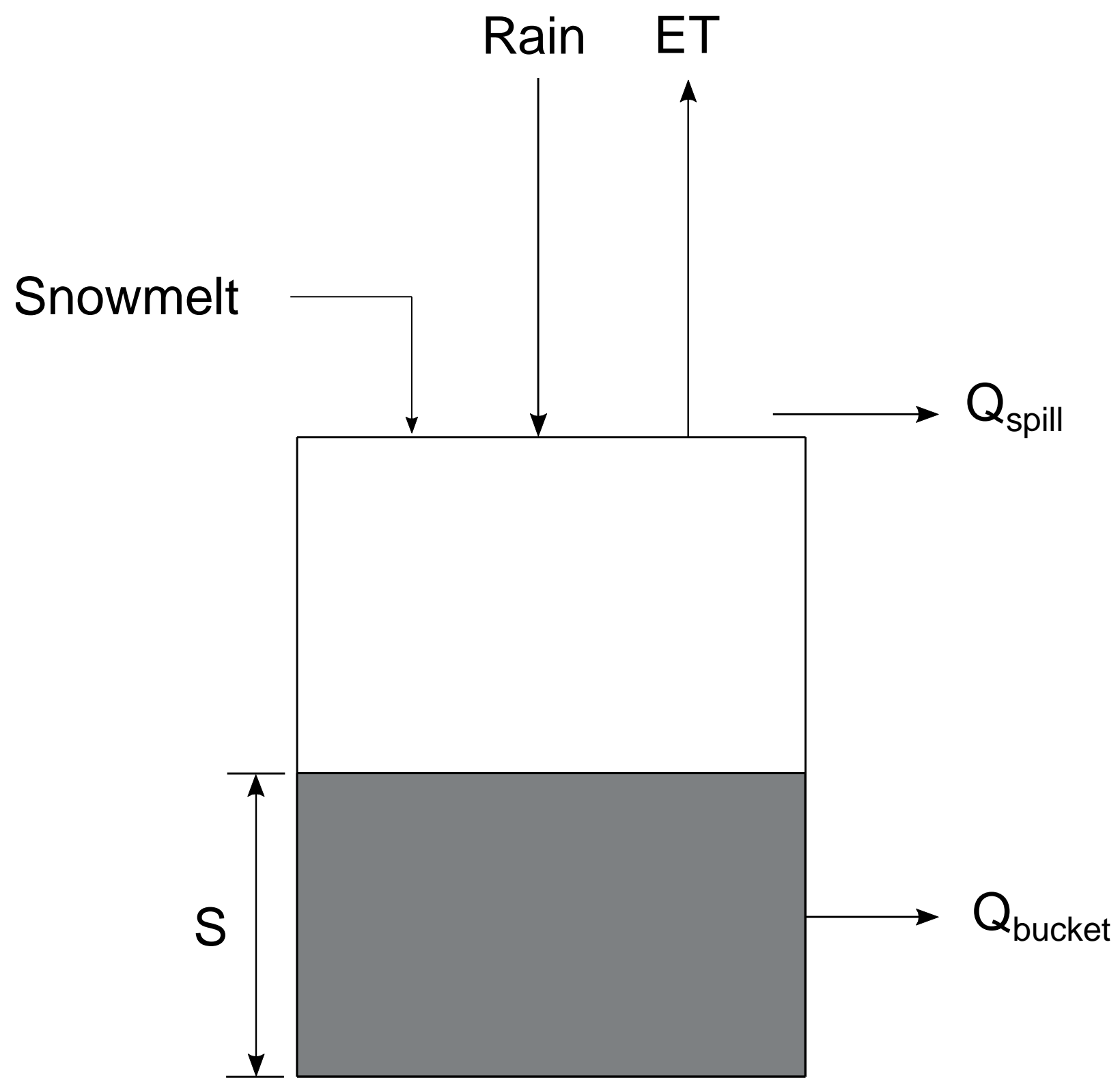

Figure 2: Schematic representation of the EXP-HYDRO model (adapted from Patil and Stieglitz [2012]). 


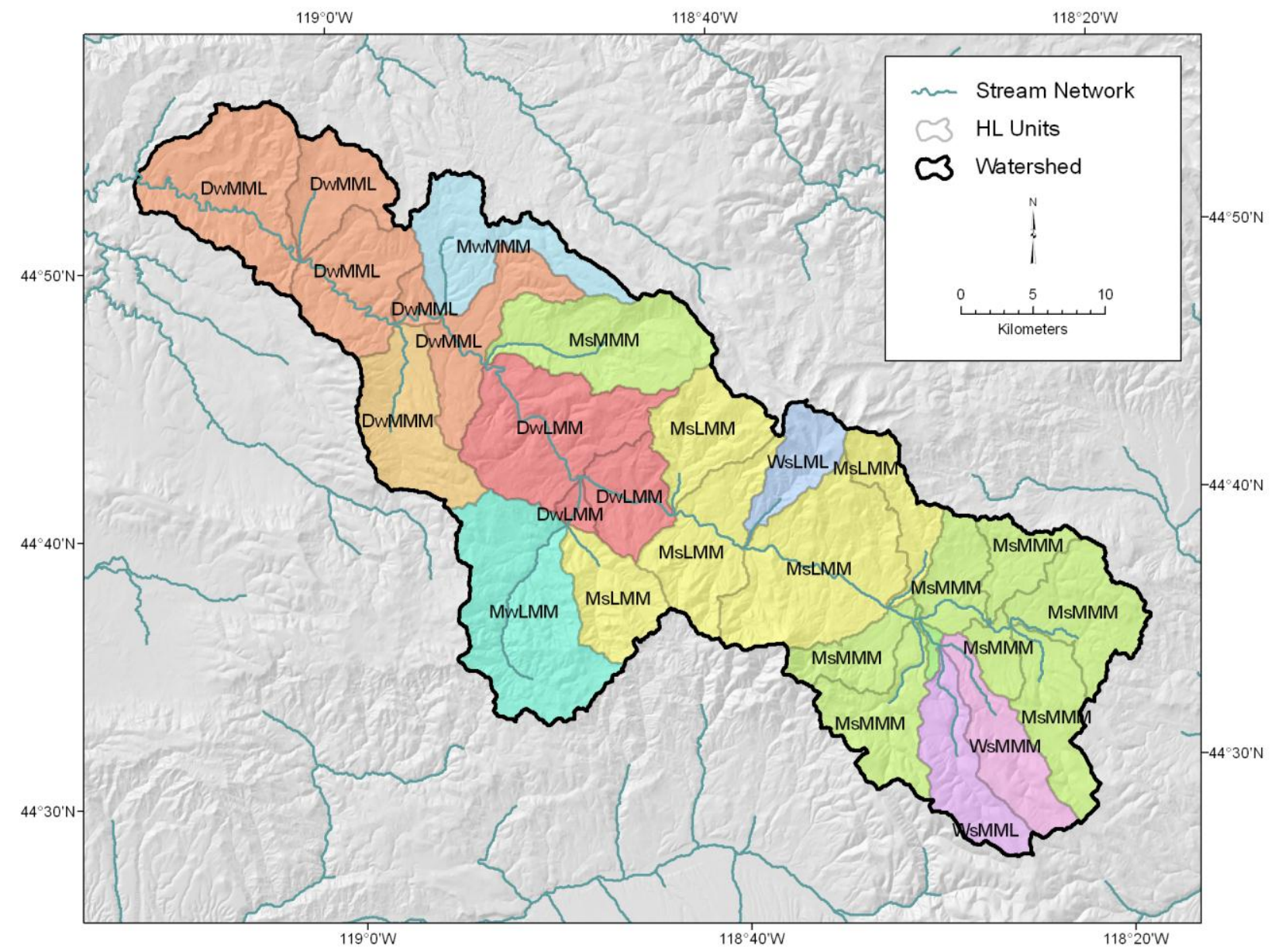

Figure 3: Map of the Middle Fork John Day River catchment showing internal heterogeneity of OHL classes at the HLU scale (Adapted from Wigington et al. [2012]). Map projected in UTM Zone 10 co-ordinate system. 
a)

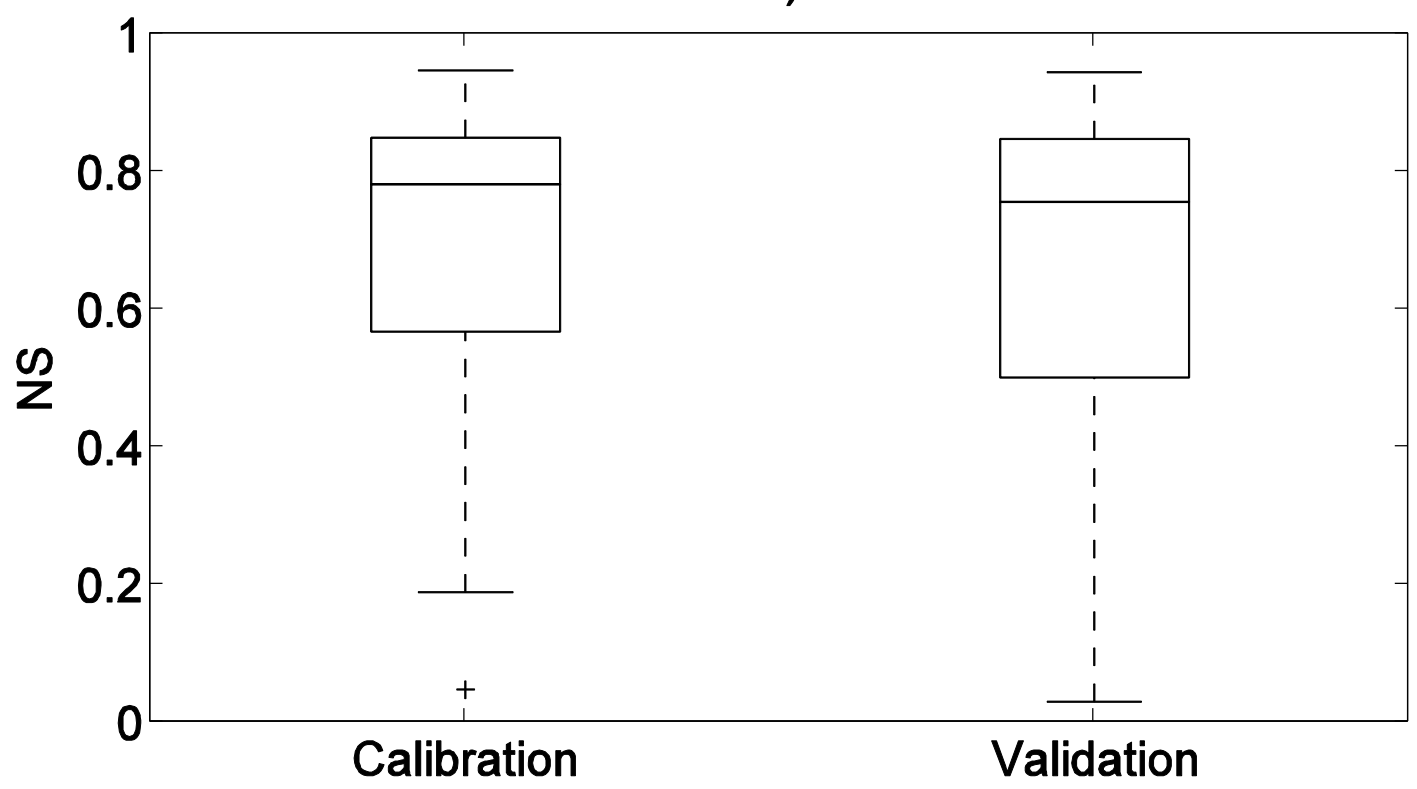

b)

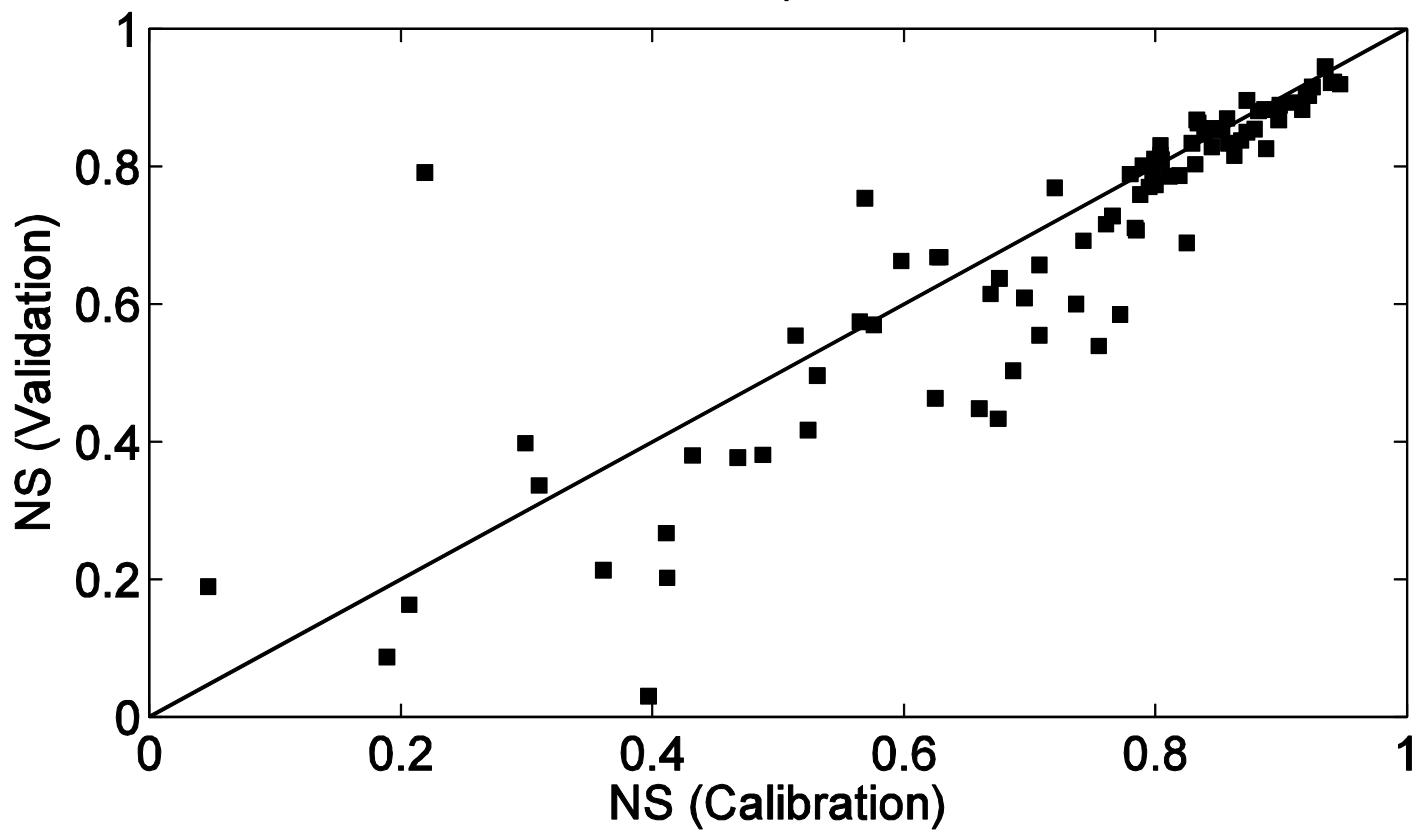

Figure 4: a) Box-and-whisker plot of NS values for calibration and validation periods, and b) 1:1 relationship of NS values for calibration and validation periods. 


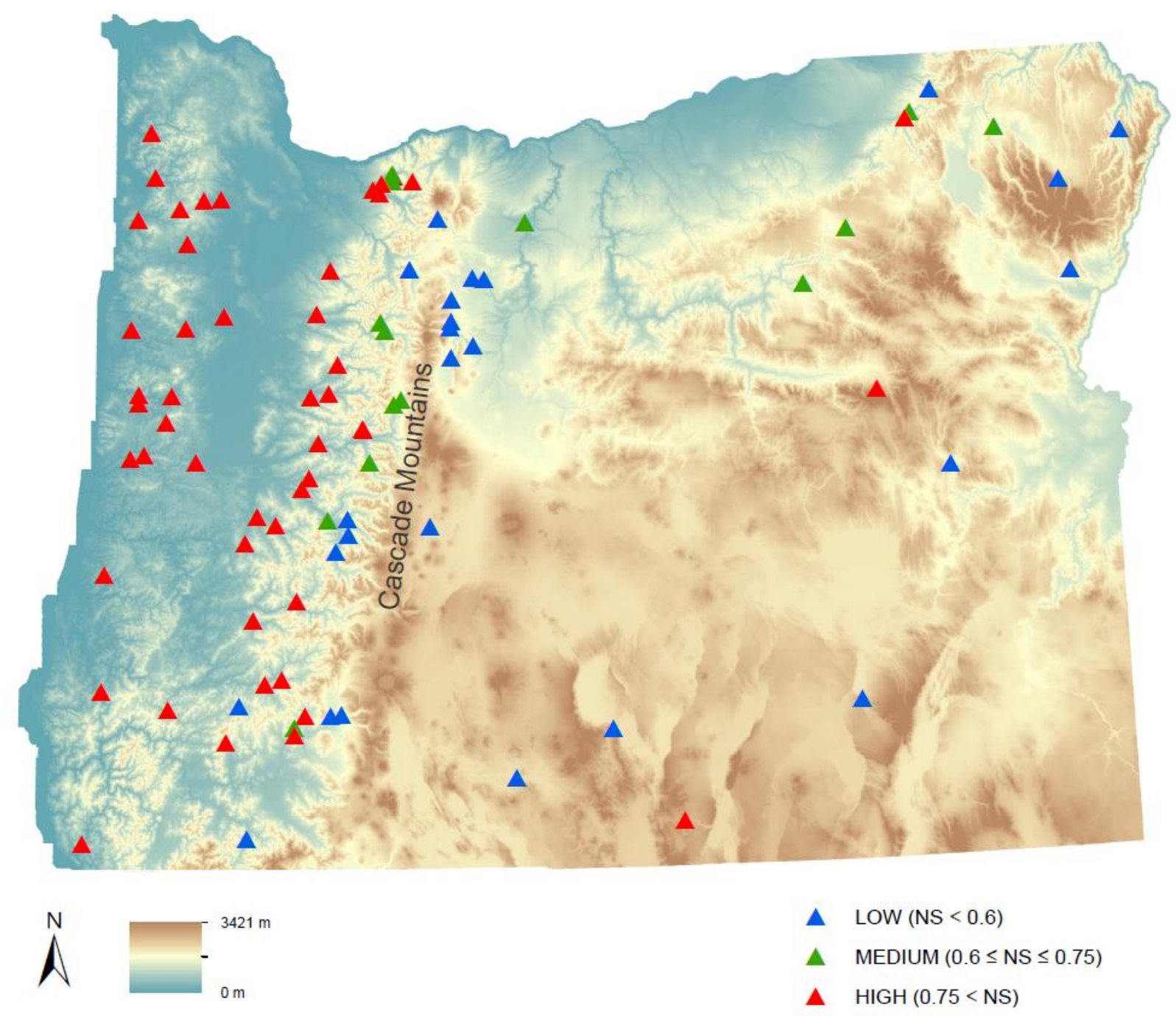

Figure 5: Classification of the 88 catchments based on calibrated NS values. Map projected in UTM Zone 10 co-ordinate system. 


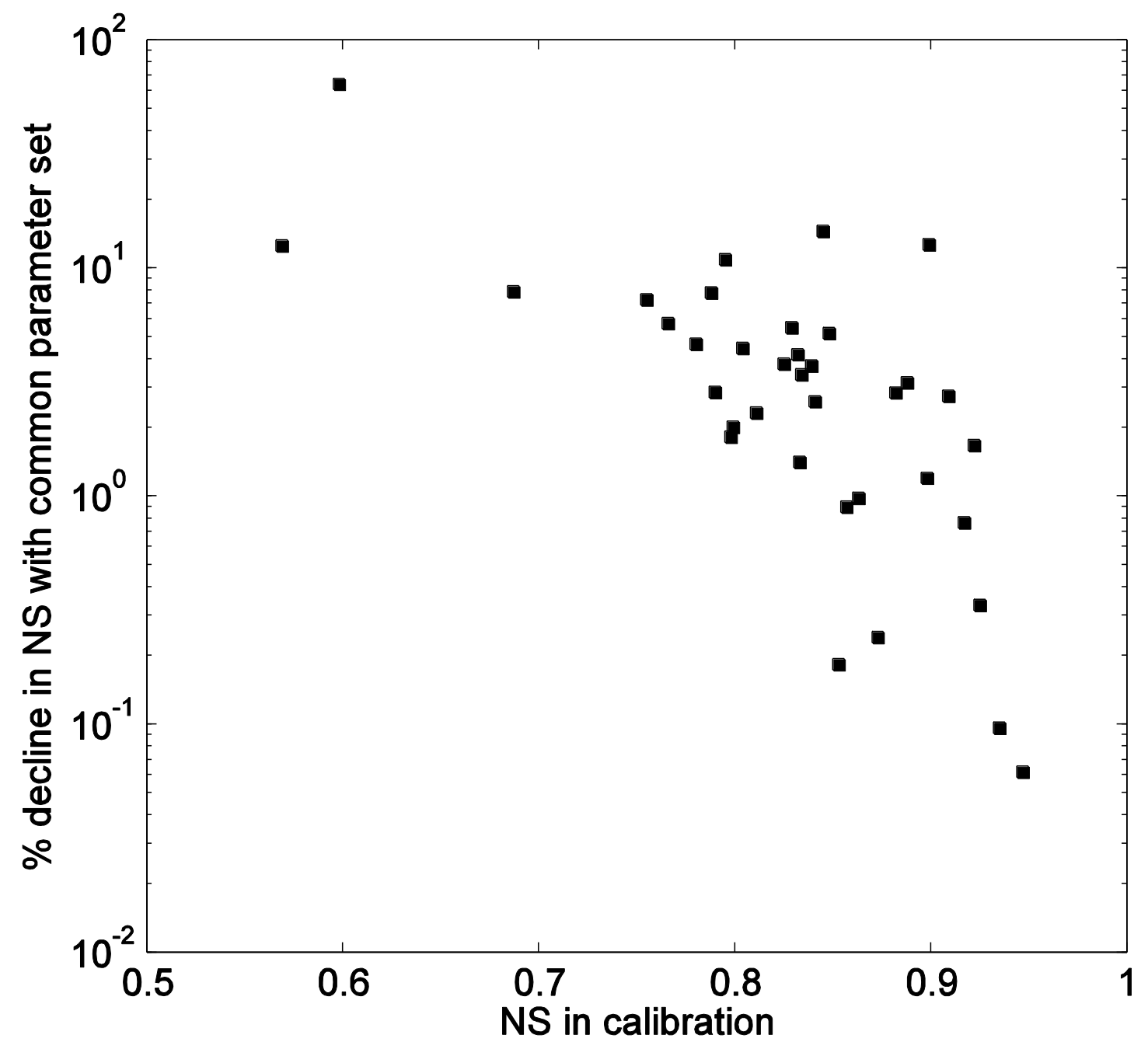

Figure 6: Relationship between calibrated NS value and the \% decline in NS with class-assigned average parameter set for the subset of 36 catchments. 
a)

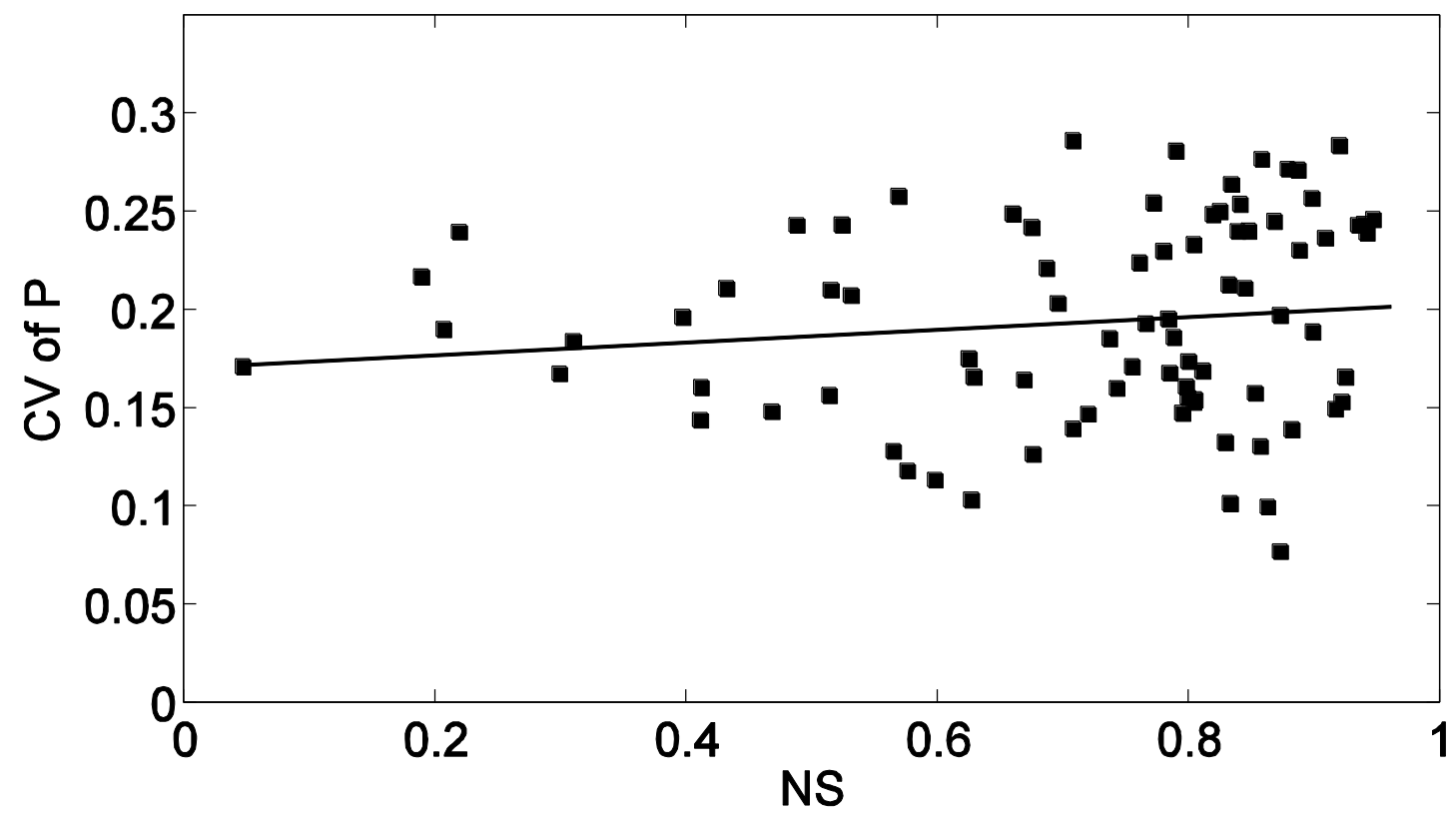

b)

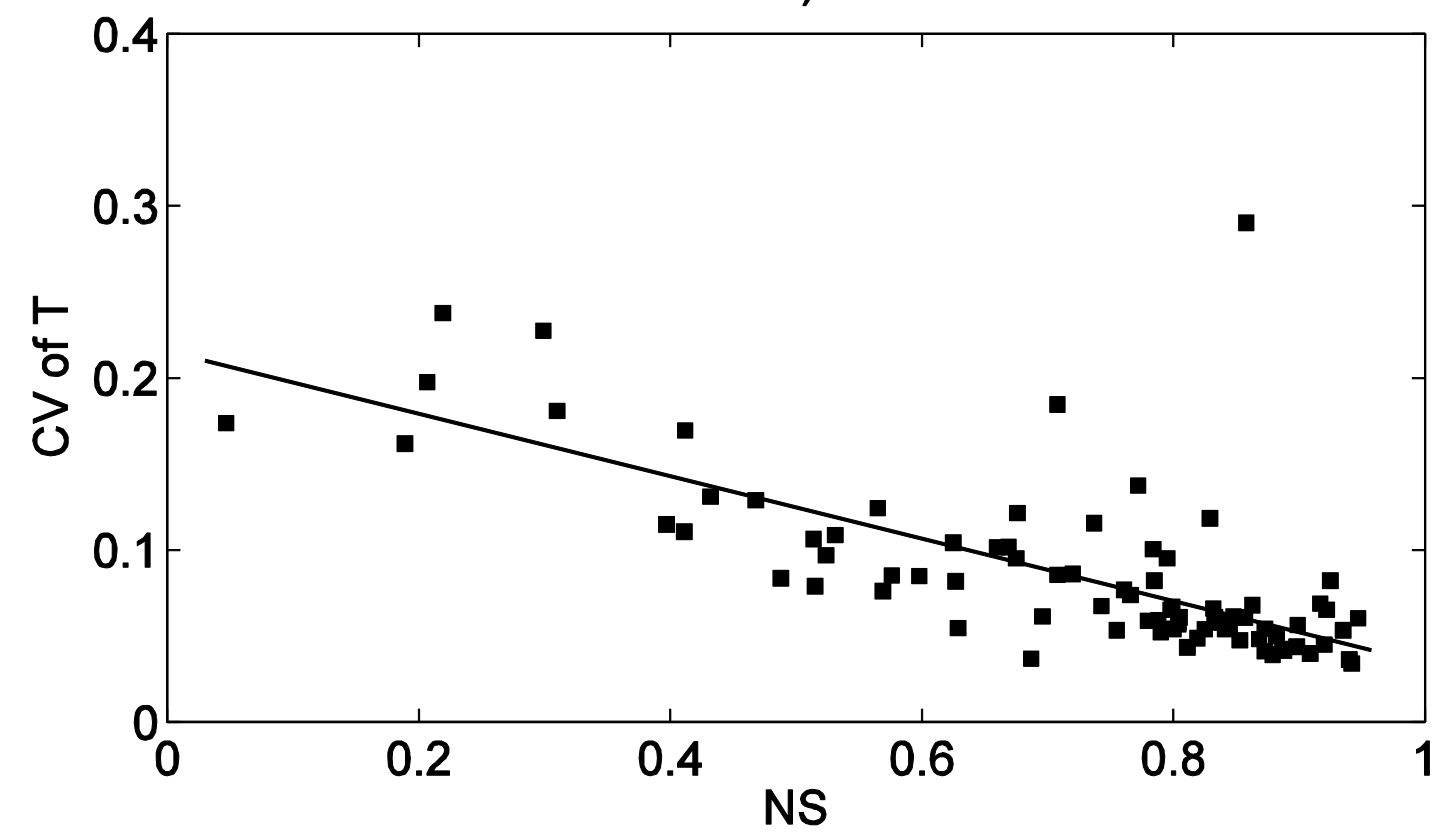

714 Figure 7: Relationship of calibration NS values with inter-annual coefficient of variation of a) Precipitation and b) Air temperature. 
Supplementary Table S1: OHL class obtained for all 88 Oregon catchments. Numbers shown in parentheses are the percentage areal coverage of each dominant property within the catchment (indicative of spatial homogeneity).

\begin{tabular}{|c|c|c|c|c|c|c|}
\hline $\begin{array}{l}\text { USGS } \\
\text { Station no. }\end{array}$ & Station Name & Climate & $\begin{array}{l}\text { Seasonality } \\
\text { of water } \\
\text { surplus }\end{array}$ & $\begin{array}{c}\text { Aquifer } \\
\text { permeability }\end{array}$ & Terrain & $\begin{array}{c}\text { Soil } \\
\text { permeability }\end{array}$ \\
\hline 10370000 & $\begin{array}{l}\text { Camas Creek near Lakeview, } \\
\text { OR }\end{array}$ & $\begin{array}{c}\mathrm{D} \\
(65.8)\end{array}$ & $\begin{array}{c}\mathrm{W} \\
(65.8)\end{array}$ & $\begin{array}{c}\mathrm{H} \\
(51.5)\end{array}$ & $\begin{array}{c}\mathrm{M} \\
(100)\end{array}$ & $\begin{array}{c}\mathrm{M} \\
(82.7)\end{array}$ \\
\hline 10384000 & $\begin{array}{l}\text { Chewaucan River near } \\
\text { Paisley, OR }\end{array}$ & $\begin{array}{c}\mathrm{M} \\
(62.5)\end{array}$ & $\begin{array}{c}\mathrm{W} \\
(58.2)\end{array}$ & $\begin{array}{c}\mathrm{L} \\
(58)\end{array}$ & $\begin{array}{c}\mathrm{M} \\
(99.3)\end{array}$ & $\begin{array}{c}\mathrm{M} \\
(73.5)\end{array}$ \\
\hline 10396000 & $\begin{array}{l}\text { Donner and Blitzen River } \\
\text { near Frenchglen, OR }\end{array}$ & $\begin{array}{c}\mathrm{W} \\
(41.7)\end{array}$ & $\begin{array}{c}\mathrm{S} \\
(61.5)\end{array}$ & $\begin{array}{c}\mathrm{M} \\
(100)\end{array}$ & $\begin{array}{c}\mathrm{M} \\
(83.7)\end{array}$ & $\begin{array}{c}\mathrm{M} \\
(58.3)\end{array}$ \\
\hline 11497500 & $\begin{array}{l}\text { Sprague River near Beatty, } \\
\text { OR }\end{array}$ & $\begin{array}{c}\mathrm{D} \\
(51.3)\end{array}$ & $\begin{array}{c}\mathrm{W} \\
(66.8)\end{array}$ & $\begin{array}{c}\mathrm{H} \\
(100)\end{array}$ & $\begin{array}{c}\mathrm{M} \\
(88.4)\end{array}$ & $\begin{array}{c}\mathrm{M} \\
(45.5)\end{array}$ \\
\hline 13216500 & $\begin{array}{l}\text { N Fk Malheur R abv Beulah } \\
\text { Res nr Beulah, OR }\end{array}$ & $\begin{array}{c}\mathrm{M} \\
(48.1)\end{array}$ & $\begin{array}{c}\mathrm{s} \\
(78.5)\end{array}$ & $\begin{array}{c}\mathrm{M} \\
(84.9)\end{array}$ & $\begin{array}{c}\text { M } \\
(100)\end{array}$ & $\begin{array}{c}\mathrm{M} \\
(78.3)\end{array}$ \\
\hline 13288200 & $\begin{array}{l}\text { Eagle Creek abv Skull } \\
\text { Creek, nr New Bridge, OR }\end{array}$ & $\begin{array}{c}\mathrm{W} \\
(56.3)\end{array}$ & $\begin{array}{c}\mathrm{s} \\
(98.8)\end{array}$ & $\begin{array}{c}\mathrm{L} \\
(74.3)\end{array}$ & $\begin{array}{c}\mathrm{M} \\
(100)\end{array}$ & $\begin{array}{c}\mathrm{L} \\
(56.3)\end{array}$ \\
\hline 13292000 & Imnaha River at Imnaha, OR & $\begin{array}{c}\mathrm{D} \\
(41.9)\end{array}$ & $\begin{array}{c}\mathrm{s} \\
(46.9)\end{array}$ & $\begin{array}{c}\mathrm{M} \\
(92.1)\end{array}$ & $\begin{array}{c}\mathrm{M} \\
(100)\end{array}$ & $\begin{array}{c}\mathrm{L} \\
(53.3)\end{array}$ \\
\hline 13329500 & $\begin{array}{l}\text { Hurricane Creek near } \\
\text { Joseph, OR }\end{array}$ & $\begin{array}{c}\mathrm{W} \\
(100)\end{array}$ & $\begin{array}{c}\mathrm{u} \\
(100)\end{array}$ & $\begin{array}{c}\mathrm{L} \\
(100)\end{array}$ & $\begin{array}{c}\mathrm{M} \\
(100)\end{array}$ & $\begin{array}{c}\mathrm{L} \\
(100)\end{array}$ \\
\hline 13331500 & $\begin{array}{l}\text { Minam River near Minam, } \\
\text { OR }\end{array}$ & $\begin{array}{c}\mathrm{W} \\
(48.8)\end{array}$ & $\begin{array}{l}\mathrm{s} \\
(87)\end{array}$ & $\begin{array}{c}\mathrm{L} \\
(53)\end{array}$ & $\begin{array}{c}\mathrm{M} \\
(100)\end{array}$ & $\begin{array}{c}\mathrm{L} \\
(57.3)\end{array}$ \\
\hline 14010000 & $\begin{array}{l}\text { South Fork Walla Walla } \\
\text { River near Milton, OR }\end{array}$ & $\begin{array}{c}\mathrm{W} \\
(100)\end{array}$ & $\begin{array}{c}\mathrm{s} \\
(100)\end{array}$ & $\begin{array}{c}\mathrm{M} \\
(100)\end{array}$ & $\begin{array}{c}\mathrm{M} \\
(100)\end{array}$ & $\begin{array}{c}\mathrm{M} \\
(100)\end{array}$ \\
\hline 14020000 & $\begin{array}{l}\text { Umatilla River abv } \\
\text { Meacham Cr, nr Gibbon, OR }\end{array}$ & $\begin{array}{c}\mathrm{W} \\
(98.4)\end{array}$ & $\begin{array}{c}\mathrm{s} \\
(98.4)\end{array}$ & $\begin{array}{c}\mathrm{M} \\
(100)\end{array}$ & $\begin{array}{c}\mathrm{M} \\
(100)\end{array}$ & $\begin{array}{c}\mathrm{M} \\
(100)\end{array}$ \\
\hline 14020300 & $\begin{array}{l}\text { Meacham Creek at Gibbon, } \\
\text { OR }\end{array}$ & $\begin{array}{c}\mathrm{W} \\
(86.6)\end{array}$ & $\begin{array}{c}\mathrm{s} \\
(80)\end{array}$ & $\begin{array}{c}\mathrm{M} \\
(100)\end{array}$ & $\begin{array}{c}\mathrm{M} \\
(100)\end{array}$ & $\begin{array}{c}\mathrm{M} \\
(100)\end{array}$ \\
\hline 14037500 & $\begin{array}{l}\text { Strawberry Cr abv Slide Cr } \\
\text { nr Prairie City, OR }\end{array}$ & $\begin{array}{c}\mathrm{M} \\
(100)\end{array}$ & $\begin{array}{c}\mathrm{s} \\
(100)\end{array}$ & $\begin{array}{c}\mathrm{M} \\
(100)\end{array}$ & $\begin{array}{c}\mathrm{M} \\
(100)\end{array}$ & $\begin{array}{c}\mathrm{L} \\
(100)\end{array}$ \\
\hline 14042500 & $\begin{array}{l}\text { Camas Creek near Ukiah, } \\
\text { OR }\end{array}$ & $\begin{array}{c}\mathrm{M} \\
(100)\end{array}$ & $\begin{array}{c}\mathrm{s} \\
(97.3)\end{array}$ & $\begin{array}{c}\mathrm{M} \\
(100)\end{array}$ & $\begin{array}{c}\mathrm{M} \\
(97.7)\end{array}$ & $\begin{array}{c}\mathrm{M} \\
(100)\end{array}$ \\
\hline 14044000 & $\begin{array}{l}\text { Middle Fork John Day River } \\
\text { at Ritter, OR }\end{array}$ & $\begin{array}{c}\mathrm{M} \\
(57.8)\end{array}$ & $\begin{array}{c}\mathrm{s} \\
(59.2)\end{array}$ & $\begin{array}{c}\mathrm{M} \\
(85)\end{array}$ & $\begin{array}{c}\mathrm{M} \\
(76.4)\end{array}$ & $\begin{array}{c}\mathrm{M} \\
(83.8)\end{array}$ \\
\hline 14054500 & $\begin{array}{l}\text { Brown Creek near La Pine, } \\
\text { OR }\end{array}$ & $\begin{array}{c}\mathrm{W} \\
(100)\end{array}$ & $\begin{array}{c}\mathrm{s} \\
(100)\end{array}$ & $\begin{array}{c}\mathrm{H} \\
(100)\end{array}$ & $\begin{array}{c}\mathrm{M} \\
(100)\end{array}$ & $\begin{array}{c}\mathrm{H} \\
(100)\end{array}$ \\
\hline 14090350 & $\begin{array}{l}\text { Jefferson Creek near Camp } \\
\text { Sherman, OR }\end{array}$ & $\begin{array}{c}\mathrm{V} \\
(100)\end{array}$ & $\begin{array}{c}\mathrm{s} \\
(100)\end{array}$ & $\begin{array}{c}\mathrm{H} \\
(100)\end{array}$ & $\begin{array}{c}\mathrm{M} \\
(100)\end{array}$ & $\begin{array}{c}\mathrm{H} \\
(100)\end{array}$ \\
\hline
\end{tabular}




\begin{tabular}{|c|c|c|c|c|c|c|}
\hline 14090400 & $\begin{array}{l}\text { Whitewater River near Camp } \\
\text { Sherman, OR }\end{array}$ & $\begin{array}{c}\mathrm{W} \\
(100)\end{array}$ & $\begin{array}{c}\mathrm{s} \\
(100)\end{array}$ & $\begin{array}{c}\mathrm{H} \\
(100)\end{array}$ & $\begin{array}{c}\mathrm{M} \\
(100)\end{array}$ & $\begin{array}{c}\mathrm{H} \\
(100)\end{array}$ \\
\hline 14091500 & $\begin{array}{l}\text { Metolius River near } \\
\text { Grandview, OR }\end{array}$ & $\begin{array}{c}\mathrm{W} \\
(53.8)\end{array}$ & $\begin{array}{c}\mathrm{s} \\
(62.7)\end{array}$ & $\begin{array}{c}\mathrm{H} \\
(100)\end{array}$ & $\begin{array}{c}\text { M } \\
(99.8)\end{array}$ & $\begin{array}{c}\mathrm{H} \\
(100)\end{array}$ \\
\hline 14092750 & $\begin{array}{l}\text { Shitike Cr, at Peters Pasture, } \\
\text { nr Warm Springs, OR }\end{array}$ & $\begin{array}{c}\mathrm{M} \\
(100)\end{array}$ & $\begin{array}{c}\mathrm{W} \\
(100)\end{array}$ & $\begin{array}{c}\mathrm{H} \\
(100)\end{array}$ & $\begin{array}{c}\mathrm{M} \\
(100)\end{array}$ & $\begin{array}{c}\mathrm{H} \\
(100)\end{array}$ \\
\hline 14095500 & $\begin{array}{l}\text { Warm Springs River near } \\
\text { Simnasho, OR }\end{array}$ & $\begin{array}{c}\mathrm{W} \\
(79.5)\end{array}$ & $\begin{array}{c}\mathrm{S} \\
(79.5)\end{array}$ & $\begin{array}{c}\mathrm{H} \\
(100)\end{array}$ & $\begin{array}{c}\mathrm{M} \\
(96.7)\end{array}$ & $\begin{array}{c}\mathrm{H} \\
(82.9)\end{array}$ \\
\hline 14096300 & $\begin{array}{l}\text { Mill Creek, nr Badger Butte, } \\
\text { nr Warm Springs, OR }\end{array}$ & $\begin{array}{c}\mathrm{W} \\
(100)\end{array}$ & $\begin{array}{c}\mathrm{s} \\
(100)\end{array}$ & $\begin{array}{c}\mathrm{H} \\
(100)\end{array}$ & $\begin{array}{c}\text { M } \\
(100)\end{array}$ & $\begin{array}{c}\mathrm{H} \\
(100)\end{array}$ \\
\hline 14096850 & $\begin{array}{l}\text { Beaver Creek, blw Quartz } \\
\text { Cr, nr Simnasho, OR }\end{array}$ & $\begin{array}{c}\mathrm{D} \\
(57.4)\end{array}$ & $\begin{array}{c}\mathrm{W} \\
(100)\end{array}$ & $\begin{array}{c}\mathrm{L} \\
(50.6)\end{array}$ & $\begin{array}{c}\mathrm{M} \\
(92.6)\end{array}$ & $\begin{array}{c}\mathrm{H} \\
(72.7)\end{array}$ \\
\hline 14101500 & $\begin{array}{l}\text { White River below Tygh } \\
\text { Valley, OR }\end{array}$ & $\begin{array}{c}\mathrm{D} \\
(38.1)\end{array}$ & $\begin{array}{l}\mathrm{W} \\
(67)\end{array}$ & $\begin{array}{c}\mathrm{H} \\
(93.4)\end{array}$ & $\begin{array}{c}\mathrm{M} \\
(87.8)\end{array}$ & $\begin{array}{c}\mathrm{L} \\
(47.9)\end{array}$ \\
\hline 14134000 & $\begin{array}{l}\text { Salmon River near } \\
\text { Government Camp, OR }\end{array}$ & $\begin{array}{c}\mathrm{V} \\
(100)\end{array}$ & $\begin{array}{c}\mathrm{s} \\
(100)\end{array}$ & $\begin{array}{c}\mathrm{H} \\
(100)\end{array}$ & $\begin{array}{c}\mathrm{M} \\
(100)\end{array}$ & $\begin{array}{c}M \\
(100)\end{array}$ \\
\hline 14137000 & $\begin{array}{l}\text { Sandy River near Marmot, } \\
\text { OR }\end{array}$ & $\begin{array}{c}\mathrm{V} \\
(100)\end{array}$ & $\begin{array}{c}s \\
(74.6)\end{array}$ & $\begin{array}{c}\mathrm{H} \\
(73.8)\end{array}$ & $\begin{array}{c}\mathrm{M} \\
(100)\end{array}$ & $\begin{array}{c}\mathrm{M} \\
(90.7)\end{array}$ \\
\hline 14138800 & $\begin{array}{l}\text { Blazed Alder Creek near } \\
\text { Rhododendron, OR }\end{array}$ & $\begin{array}{c}\mathrm{V} \\
(100)\end{array}$ & $\begin{array}{c}\mathrm{S} \\
(100)\end{array}$ & $\begin{array}{c}\mathrm{H} \\
(100)\end{array}$ & $\begin{array}{c}\mathrm{M} \\
(100)\end{array}$ & $\begin{array}{c}M \\
(100)\end{array}$ \\
\hline 14138870 & $\begin{array}{l}\text { Fir Creek near Brightwood, } \\
\text { OR }\end{array}$ & $\begin{array}{c}\mathrm{V} \\
(100)\end{array}$ & $\begin{array}{c}\mathrm{W} \\
(100)\end{array}$ & $\begin{array}{c}\mathrm{H} \\
(100)\end{array}$ & $\begin{array}{c}\mathrm{M} \\
(100)\end{array}$ & $\begin{array}{c}\mathrm{M} \\
(100)\end{array}$ \\
\hline 14138900 & $\begin{array}{l}\text { North Fork Bull Run River } \\
\text { near Multnomah Falls, OR }\end{array}$ & $\begin{array}{c}\mathrm{V} \\
(100)\end{array}$ & $\begin{array}{c}\mathrm{W} \\
(100)\end{array}$ & $\begin{array}{c}\mathrm{H} \\
(100)\end{array}$ & $\begin{array}{c}\mathrm{M} \\
(100)\end{array}$ & $\begin{array}{c}\mathrm{M} \\
(100)\end{array}$ \\
\hline 14139700 & $\begin{array}{l}\text { Cedar Creek near } \\
\text { Brightwood, OR }\end{array}$ & $\begin{array}{c}\mathrm{V} \\
(100)\end{array}$ & $\begin{array}{c}\mathrm{W} \\
(100)\end{array}$ & $\begin{array}{c}\mathrm{H} \\
(100)\end{array}$ & $\begin{array}{c}\mathrm{M} \\
(100)\end{array}$ & $\begin{array}{c}M \\
(100)\end{array}$ \\
\hline 14139800 & $\begin{array}{l}\text { South Fork Bull Run River } \\
\text { near Bull Run, OR }\end{array}$ & $\begin{array}{c}\mathrm{V} \\
(100)\end{array}$ & $\begin{array}{c}\mathrm{W} \\
(100)\end{array}$ & $\begin{array}{c}\mathrm{H} \\
(100)\end{array}$ & $\begin{array}{c}\mathrm{M} \\
(100)\end{array}$ & $\begin{array}{c}M \\
(100)\end{array}$ \\
\hline 14141500 & $\begin{array}{l}\text { Little Sandy River near Bull } \\
\text { Run, OR }\end{array}$ & $\begin{array}{c}\mathrm{V} \\
(100)\end{array}$ & $\begin{array}{c}\mathrm{W} \\
(100)\end{array}$ & $\begin{array}{c}\mathrm{L} \\
(100)\end{array}$ & $\begin{array}{c}\mathrm{M} \\
(100)\end{array}$ & $\begin{array}{c}M \\
(100)\end{array}$ \\
\hline 14144800 & $\begin{array}{l}\text { Middle Fork Willamette } \\
\text { River nr Oakridge, OR }\end{array}$ & $\begin{array}{c}\mathrm{V} \\
(55.8)\end{array}$ & $\begin{array}{c}\mathrm{S} \\
(55.8)\end{array}$ & $\begin{array}{c}\mathrm{H} \\
(68)\end{array}$ & $\begin{array}{c}\mathrm{M} \\
(100)\end{array}$ & $\begin{array}{c}\mathrm{M} \\
(63.7)\end{array}$ \\
\hline 14144900 & $\begin{array}{l}\text { Hills } \mathrm{Cr} \text { abv Hills } \mathrm{Cr} \text { Res, nr } \\
\text { Oakridge, OR }\end{array}$ & $\begin{array}{c}\mathrm{W} \\
(100)\end{array}$ & $\begin{array}{c}\mathrm{W} \\
(100)\end{array}$ & $\begin{array}{c}\mathrm{L} \\
(100)\end{array}$ & $\begin{array}{c}\mathrm{M} \\
(100)\end{array}$ & $\begin{array}{c}M \\
(100)\end{array}$ \\
\hline 14146500 & $\begin{array}{l}\text { Salmon Creek near } \\
\text { Oakridge, OR }\end{array}$ & $\begin{array}{c}\mathrm{V} \\
(64.7)\end{array}$ & $\begin{array}{c}\mathrm{s} \\
(64.7)\end{array}$ & $\begin{array}{c}\mathrm{H} \\
(75.1)\end{array}$ & $\underset{(56.3)}{M}$ & $\underset{(56.3)}{M}$ \\
\hline 14147500 & $\begin{array}{l}\text { N Fk of M Fk Willamette R } \\
\text { nr Oakridge, OR }\end{array}$ & $\begin{array}{c}\mathrm{V} \\
(51.3)\end{array}$ & $\begin{array}{c}\mathrm{W} \\
(73.9)\end{array}$ & $\begin{array}{c}\mathrm{H} \\
(53.9)\end{array}$ & $\begin{array}{c}\mathrm{M} \\
(100)\end{array}$ & $\begin{array}{c}\mathrm{M} \\
(59.4)\end{array}$ \\
\hline
\end{tabular}




\begin{tabular}{|c|c|c|c|c|c|c|}
\hline 14150300 & Fall Creek near Lowell, OR & $\begin{array}{c}\mathrm{V} \\
(60.5)\end{array}$ & $\begin{array}{c}\mathrm{W} \\
(100)\end{array}$ & $\begin{array}{c}\mathrm{L} \\
(100)\end{array}$ & $\begin{array}{c}\mathrm{M} \\
(100)\end{array}$ & $\begin{array}{c}\mathrm{M} \\
(71.1)\end{array}$ \\
\hline 14150800 & $\begin{array}{l}\text { Winberry Creek near Lowell, } \\
\text { OR }\end{array}$ & $\begin{array}{c}\mathrm{W} \\
(100)\end{array}$ & $\begin{array}{c}\mathrm{W} \\
(100)\end{array}$ & $\begin{array}{c}\mathrm{L} \\
(100)\end{array}$ & $\begin{array}{c}\mathrm{M} \\
(100)\end{array}$ & $\begin{array}{c}\mathrm{M} \\
(80.2)\end{array}$ \\
\hline 14152500 & $\begin{array}{l}\text { Coast Fork Willamette River } \\
\text { at London, OR }\end{array}$ & $\begin{array}{c}\mathrm{W} \\
(100)\end{array}$ & $\begin{array}{c}\mathrm{W} \\
(100)\end{array}$ & $\begin{array}{c}\mathrm{L} \\
(100)\end{array}$ & $\begin{array}{c}\mathrm{M} \\
(100)\end{array}$ & $\begin{array}{c}\mathrm{L} \\
(100)\end{array}$ \\
\hline 14154500 & Row River near Dorena, OR & $\begin{array}{c}\mathrm{W} \\
(78.7)\end{array}$ & $\begin{array}{c}\mathrm{W} \\
(100)\end{array}$ & $\begin{array}{c}\mathrm{L} \\
(100)\end{array}$ & $\begin{array}{c}\mathrm{M} \\
(100)\end{array}$ & $\begin{array}{c}\mathrm{M} \\
(72.4)\end{array}$ \\
\hline 14156500 & $\begin{array}{l}\text { Mosby } \mathrm{Cr} \text { at mouth, } \mathrm{nr} \\
\text { Cottage Grove, OR }\end{array}$ & $\begin{array}{c}\mathrm{W} \\
(100)\end{array}$ & $\begin{array}{c}\mathrm{W} \\
(100)\end{array}$ & $\begin{array}{c}\mathrm{L} \\
(100)\end{array}$ & $\begin{array}{c}\mathrm{M} \\
(100)\end{array}$ & $\begin{array}{c}\mathrm{L} \\
(100)\end{array}$ \\
\hline 14158500 & $\begin{array}{l}\text { McKenzie River at outlet of } \\
\text { Clear Lake, OR }\end{array}$ & $\begin{array}{c}\mathrm{V} \\
(100)\end{array}$ & $\begin{array}{c}\mathrm{s} \\
(100)\end{array}$ & $\begin{array}{c}\mathrm{H} \\
(100)\end{array}$ & $\begin{array}{c}\mathrm{M} \\
(99)\end{array}$ & $\begin{array}{c}\mathrm{M} \\
(76.1)\end{array}$ \\
\hline 14158790 & $\begin{array}{l}\text { Smith } \mathrm{R} \text { abv Smith } \mathrm{R} \text { res nr } \\
\text { Belknap Springs, OR }\end{array}$ & $\begin{array}{c}\mathrm{V} \\
(100)\end{array}$ & $\begin{array}{c}\mathrm{s} \\
(100)\end{array}$ & $\begin{array}{c}\mathrm{H} \\
(100)\end{array}$ & $\begin{array}{c}M \\
(100)\end{array}$ & $\begin{array}{c}\mathrm{M} \\
(100)\end{array}$ \\
\hline 14159200 & $\begin{array}{l}\text { So Fk McKenzie River abv } \\
\text { Cougar Lk nr Rainbow, OR }\end{array}$ & $\begin{array}{c}\mathrm{V} \\
(100)\end{array}$ & $\begin{array}{c}\mathrm{w} \\
(60.5)\end{array}$ & $\begin{array}{c}\mathrm{L} \\
(56.3)\end{array}$ & $\begin{array}{c}\mathrm{M} \\
(100)\end{array}$ & $\begin{array}{c}\mathrm{M} \\
(100)\end{array}$ \\
\hline 14161100 & $\begin{array}{l}\text { Blue River below Tidbits } \\
\text { Creek, nr Blue River, OR }\end{array}$ & $\begin{array}{c}\mathrm{V} \\
(100)\end{array}$ & $\begin{array}{c}\mathrm{W} \\
(100)\end{array}$ & $\begin{array}{c}\mathrm{L} \\
(100)\end{array}$ & $\begin{array}{c}\mathrm{M} \\
(100)\end{array}$ & $\begin{array}{c}\mathrm{M} \\
(100)\end{array}$ \\
\hline 14161500 & $\begin{array}{l}\text { Lookout Creek near Blue } \\
\text { River, OR }\end{array}$ & $\begin{array}{c}\mathrm{V} \\
(100)\end{array}$ & $\begin{array}{c}\mathrm{W} \\
(100)\end{array}$ & $\begin{array}{c}\mathrm{H} \\
(100)\end{array}$ & $\begin{array}{c}\mathrm{M} \\
(100)\end{array}$ & $\begin{array}{c}\mathrm{M} \\
(100)\end{array}$ \\
\hline 14163000 & Gate Creek at Vida, OR & $\begin{array}{c}\mathrm{V} \\
(61.4)\end{array}$ & $\begin{array}{c}\mathrm{W} \\
(100)\end{array}$ & $\begin{array}{c}\mathrm{L} \\
(100)\end{array}$ & $\begin{array}{c}\mathrm{M} \\
(100)\end{array}$ & $\begin{array}{c}\mathrm{L} \\
(52)\end{array}$ \\
\hline 14166500 & $\begin{array}{l}\text { Long Tom River near Noti, } \\
\text { OR }\end{array}$ & $\begin{array}{c}\mathrm{W} \\
(100)\end{array}$ & $\begin{array}{c}\mathrm{W} \\
(100)\end{array}$ & $\begin{array}{c}\mathrm{L} \\
(99.1)\end{array}$ & $\begin{array}{c}\mathrm{M} \\
(98.8)\end{array}$ & $\begin{array}{c}\mathrm{L} \\
(100)\end{array}$ \\
\hline 14178000 & $\begin{array}{l}\text { North Santiam River below } \\
\text { Boulder Cr, nr Detroit, OR }\end{array}$ & $\begin{array}{c}\mathrm{V} \\
(100)\end{array}$ & $\begin{array}{c}\mathrm{S} \\
(80.4)\end{array}$ & $\begin{array}{c}\mathrm{H} \\
(94.2)\end{array}$ & $\begin{array}{c}M \\
(100)\end{array}$ & $\begin{array}{c}\mathrm{M} \\
(54.3)\end{array}$ \\
\hline 14179000 & $\begin{array}{l}\text { Breitenbush } \mathrm{R} \text { abv French } \mathrm{Cr} \\
\text { nr Detroit, OR }\end{array}$ & $\begin{array}{c}\mathrm{V} \\
(100)\end{array}$ & $\begin{array}{c}\mathrm{W} \\
(56.6)\end{array}$ & $\begin{array}{c}\mathrm{L} \\
(56.6)\end{array}$ & $\begin{array}{c}\mathrm{M} \\
(100)\end{array}$ & $\begin{array}{c}\mathrm{M} \\
(56.6)\end{array}$ \\
\hline 14182500 & $\begin{array}{l}\text { Little North Santiam River } \\
\text { near Mehama, OR }\end{array}$ & $\begin{array}{c}\mathrm{V} \\
(100)\end{array}$ & $\begin{array}{c}\mathrm{W} \\
(100)\end{array}$ & $\begin{array}{c}\mathrm{L} \\
(100)\end{array}$ & $\begin{array}{c}\mathrm{M} \\
(100)\end{array}$ & $\begin{array}{c}M \\
(100)\end{array}$ \\
\hline 14185000 & $\begin{array}{l}\text { South Santiam below } \\
\text { Cascadia, OR }\end{array}$ & $\begin{array}{c}\mathrm{V} \\
(91.9)\end{array}$ & $\begin{array}{c}\mathrm{W} \\
(100)\end{array}$ & $\begin{array}{c}\mathrm{L} \\
(100)\end{array}$ & $\begin{array}{c}\mathrm{M} \\
(100)\end{array}$ & $\begin{array}{c}\mathrm{M} \\
(81.5)\end{array}$ \\
\hline 14185900 & $\begin{array}{l}\text { Quartzville Creek near } \\
\text { Cascadia, OR }\end{array}$ & $\begin{array}{c}\mathrm{V} \\
(100)\end{array}$ & $\begin{array}{c}\mathrm{W} \\
(100)\end{array}$ & $\begin{array}{c}\mathrm{L} \\
(100)\end{array}$ & $\begin{array}{c}\mathrm{M} \\
(100)\end{array}$ & $\begin{array}{c}M \\
(100)\end{array}$ \\
\hline 14187000 & Wiley Creek near Foster, OR & $\begin{array}{c}\mathrm{V} \\
(98.8)\end{array}$ & $\begin{array}{c}\mathrm{W} \\
(100)\end{array}$ & $\begin{array}{c}\mathrm{L} \\
(100)\end{array}$ & $\begin{array}{c}\mathrm{M} \\
(100)\end{array}$ & $\underset{(66.3)}{M}$ \\
\hline 14189500 & $\begin{array}{l}\text { Luckiamute River near } \\
\text { Hoskins, OR }\end{array}$ & $\begin{array}{c}\mathrm{V} \\
(100)\end{array}$ & $\begin{array}{c}\mathrm{W} \\
(100)\end{array}$ & $\begin{array}{c}\mathrm{L} \\
(100)\end{array}$ & $\begin{array}{c}\text { M } \\
(100)\end{array}$ & $\begin{array}{c}\mathrm{L} \\
(100)\end{array}$ \\
\hline
\end{tabular}




\begin{tabular}{|c|c|c|c|c|c|c|}
\hline 14190500 & $\begin{array}{l}\text { Luckiamute River near } \\
\text { Suver, OR }\end{array}$ & $\begin{array}{c}\mathrm{W} \\
(53.1)\end{array}$ & $\begin{array}{c}\mathrm{W} \\
(100)\end{array}$ & $\begin{array}{c}\mathrm{L} \\
(96.1)\end{array}$ & $\begin{array}{l}\mathrm{M} \\
(70)\end{array}$ & $\begin{array}{c}\mathrm{L} \\
(53.1)\end{array}$ \\
\hline 14193000 & $\begin{array}{l}\text { Willamina Creek near } \\
\text { Willamina, OR }\end{array}$ & $\begin{array}{c}\mathrm{V} \\
(96.1)\end{array}$ & $\begin{array}{c}\mathrm{W} \\
(100)\end{array}$ & $\begin{array}{c}\mathrm{L} \\
(100)\end{array}$ & $\begin{array}{c}\mathrm{M} \\
(96.1)\end{array}$ & $\begin{array}{c}\mathrm{L} \\
(100)\end{array}$ \\
\hline 14194300 & $\begin{array}{l}\text { North Yamhill River near } \\
\text { Fairdale, OR }\end{array}$ & $\begin{array}{c}\mathrm{V} \\
(100)\end{array}$ & $\begin{array}{c}\mathrm{W} \\
(100)\end{array}$ & $\begin{array}{c}\mathrm{L} \\
(100)\end{array}$ & $\begin{array}{c}\mathrm{M} \\
(100)\end{array}$ & $\begin{array}{c}\mathrm{L} \\
(100)\end{array}$ \\
\hline 14197000 & North Yamhill R at Pike, OR & $\begin{array}{c}\mathrm{V} \\
(64.8)\end{array}$ & $\begin{array}{c}\mathrm{W} \\
(100)\end{array}$ & $\begin{array}{c}\mathrm{L} \\
(100)\end{array}$ & $\begin{array}{c}\mathrm{M} \\
(100)\end{array}$ & $\begin{array}{c}\mathrm{L} \\
(100)\end{array}$ \\
\hline 14198500 & $\begin{array}{l}\text { Molalla R abv PC nr } \\
\text { Wilhoit, OR }\end{array}$ & $\begin{array}{c}\mathrm{V} \\
(100)\end{array}$ & $\begin{array}{c}\mathrm{W} \\
(100)\end{array}$ & $\begin{array}{c}\mathrm{L} \\
(100)\end{array}$ & $\begin{array}{c}\mathrm{M} \\
(100)\end{array}$ & $\begin{array}{c}M \\
(100)\end{array}$ \\
\hline 14208000 & $\begin{array}{l}\text { Clackamas River at Big } \\
\text { Bottom, OR }\end{array}$ & $\begin{array}{c}\mathrm{V} \\
(100)\end{array}$ & $\begin{array}{c}\mathrm{s} \\
(88.3)\end{array}$ & $\begin{array}{c}\mathrm{H} \\
(100)\end{array}$ & $\begin{array}{c}\mathrm{M} \\
(99.7)\end{array}$ & $\begin{array}{c}\mathrm{M} \\
(73.2)\end{array}$ \\
\hline 14301000 & $\begin{array}{l}\text { Nehalem River near Foss, } \\
\text { OR }\end{array}$ & $\begin{array}{c}\mathrm{V} \\
(75.9)\end{array}$ & $\begin{array}{c}\mathrm{W} \\
(100)\end{array}$ & $\begin{array}{c}\mathrm{L} \\
(98)\end{array}$ & $\begin{array}{c}\mathrm{M} \\
(85.5)\end{array}$ & $\begin{array}{c}\mathrm{L} \\
(55.9)\end{array}$ \\
\hline 14301500 & $\begin{array}{l}\text { Wilson River near } \\
\text { Tillamook, OR }\end{array}$ & $\begin{array}{c}\mathrm{V} \\
(100)\end{array}$ & $\begin{array}{c}\mathrm{W} \\
(100)\end{array}$ & $\begin{array}{c}\mathrm{L} \\
(100)\end{array}$ & $\begin{array}{c}\mathrm{M} \\
(100)\end{array}$ & $\begin{array}{c}\mathrm{L} \\
(100)\end{array}$ \\
\hline 14303200 & Tucca Creek near Blaine, OR & $\begin{array}{c}\mathrm{V} \\
(100)\end{array}$ & $\begin{array}{c}\mathrm{W} \\
(100)\end{array}$ & $\begin{array}{c}\mathrm{L} \\
(100)\end{array}$ & $\begin{array}{c}\mathrm{M} \\
(100)\end{array}$ & $\begin{array}{c}\mathrm{L} \\
(100)\end{array}$ \\
\hline 14303600 & $\begin{array}{l}\text { Nestucca River near Beaver, } \\
\text { OR }\end{array}$ & $\begin{array}{c}\mathrm{V} \\
(100)\end{array}$ & $\begin{array}{c}\mathrm{W} \\
(100)\end{array}$ & $\begin{array}{c}\mathrm{L} \\
(100)\end{array}$ & $\begin{array}{c}\mathrm{M} \\
(100)\end{array}$ & $\begin{array}{c}\mathrm{L} \\
(94)\end{array}$ \\
\hline 14305500 & Siletz River at Siletz, OR & $\begin{array}{c}\mathrm{V} \\
(100)\end{array}$ & $\begin{array}{c}\mathrm{W} \\
(100)\end{array}$ & $\begin{array}{c}\mathrm{L} \\
(100)\end{array}$ & $\begin{array}{c}\mathrm{M} \\
(98.1)\end{array}$ & $\begin{array}{c}\mathrm{L} \\
(63.3)\end{array}$ \\
\hline 14306100 & N Fk Alsea R at Alsea, OR & $\begin{array}{c}\mathrm{V} \\
(76.9)\end{array}$ & $\begin{array}{c}\mathrm{W} \\
(100)\end{array}$ & $\begin{array}{c}\mathrm{L} \\
(100)\end{array}$ & $\begin{array}{c}\mathrm{M} \\
(100)\end{array}$ & $\begin{array}{c}\mathrm{L} \\
(100)\end{array}$ \\
\hline 14306340 & $\begin{array}{l}\text { East Fork Lobster Creek near } \\
\text { Alsea, OR }\end{array}$ & $\begin{array}{c}\mathrm{V} \\
(100)\end{array}$ & $\begin{array}{c}\mathrm{W} \\
(100)\end{array}$ & $\begin{array}{c}\mathrm{L} \\
(100)\end{array}$ & $\begin{array}{c}\mathrm{M} \\
(100)\end{array}$ & $\begin{array}{c}M \\
(100)\end{array}$ \\
\hline 14306400 & Five Rivers nr Fisher, OR & $\begin{array}{c}\mathrm{V} \\
(100)\end{array}$ & $\begin{array}{c}\mathrm{W} \\
(100)\end{array}$ & $\begin{array}{c}\mathrm{L} \\
(100)\end{array}$ & $\begin{array}{c}\mathrm{M} \\
(100)\end{array}$ & $\begin{array}{c}M \\
(100)\end{array}$ \\
\hline 14306500 & $\begin{array}{l}\text { Alsea River near Tidewater, } \\
\text { OR }\end{array}$ & $\begin{array}{l}\mathrm{V} \\
(70)\end{array}$ & $\begin{array}{c}\mathrm{W} \\
(100)\end{array}$ & $\begin{array}{c}\mathrm{L} \\
(100)\end{array}$ & $\begin{array}{c}\mathrm{M} \\
(100)\end{array}$ & $\begin{array}{c}\mathrm{M} \\
(51.1)\end{array}$ \\
\hline 14307580 & $\begin{array}{l}\text { Lake Creek near Deadwood, } \\
\text { OR }\end{array}$ & $\begin{array}{c}\mathrm{V} \\
(53)\end{array}$ & $\begin{array}{c}\mathrm{w} \\
(100)\end{array}$ & $\begin{array}{c}\mathrm{L} \\
(100)\end{array}$ & $\begin{array}{c}\mathrm{M} \\
(100)\end{array}$ & $\begin{array}{c}M \\
(100)\end{array}$ \\
\hline 14307620 & $\begin{array}{l}\text { Siuslaw River near } \\
\text { Mapleton, OR }\end{array}$ & $\begin{array}{c}\mathrm{W} \\
(64.8)\end{array}$ & $\begin{array}{c}\mathrm{W} \\
(100)\end{array}$ & $\begin{array}{c}\mathrm{L} \\
(100)\end{array}$ & $\begin{array}{c}\mathrm{M} \\
(99.9)\end{array}$ & $\begin{array}{c}M \\
(59)\end{array}$ \\
\hline 14307700 & Jackson Creek nr Tiller, OR & $\begin{array}{c}\mathrm{W} \\
(100)\end{array}$ & $\begin{array}{c}\mathrm{W} \\
(100)\end{array}$ & $\begin{array}{c}\mathrm{L} \\
(100)\end{array}$ & $\begin{array}{c}\mathrm{M} \\
(100)\end{array}$ & $\begin{array}{c}M \\
(100)\end{array}$ \\
\hline 14308000 & $\begin{array}{l}\text { South Umpqua River at } \\
\text { Tiller, OR }\end{array}$ & $\begin{array}{c}\mathrm{W} \\
(100)\end{array}$ & $\begin{array}{c}\mathrm{w} \\
(100)\end{array}$ & $\begin{array}{c}\mathrm{L} \\
(100)\end{array}$ & $\begin{array}{c}\mathrm{M} \\
(100)\end{array}$ & $\begin{array}{c}M \\
(100)\end{array}$ \\
\hline
\end{tabular}




\begin{tabular}{|c|c|c|c|c|c|c|}
\hline 14308990 & $\begin{array}{l}\text { Cow Creek abv Galesville } \\
\text { res, nr Azalea, OR }\end{array}$ & $\begin{array}{c}\mathrm{W} \\
(100)\end{array}$ & $\begin{array}{c}\mathrm{W} \\
(100)\end{array}$ & $\begin{array}{c}\mathrm{L} \\
(80.6)\end{array}$ & $\begin{array}{c}\mathrm{M} \\
(100)\end{array}$ & $\begin{array}{c}\mathrm{M} \\
(80.6)\end{array}$ \\
\hline 14309500 & $\begin{array}{l}\text { West Fork Cow Creek near } \\
\text { Glendale, OR }\end{array}$ & $\begin{array}{c}\mathrm{W} \\
(100)\end{array}$ & $\begin{array}{c}\mathrm{W} \\
(100)\end{array}$ & $\begin{array}{c}\mathrm{L} \\
(100)\end{array}$ & $\begin{array}{c}\mathrm{M} \\
(100)\end{array}$ & $\begin{array}{c}M \\
(100)\end{array}$ \\
\hline 14316700 & $\begin{array}{l}\text { Steamboat Creek near Glide, } \\
\text { OR }\end{array}$ & $\begin{array}{c}\mathrm{W} \\
(83.1)\end{array}$ & $\begin{array}{c}\mathrm{W} \\
(100)\end{array}$ & $\begin{array}{c}\mathrm{L} \\
(100)\end{array}$ & $\begin{array}{c}\mathrm{M} \\
(100)\end{array}$ & $\begin{array}{c}M \\
(100)\end{array}$ \\
\hline 14318000 & Little River at Peel, OR & $\begin{array}{l}\mathrm{W} \\
(94)\end{array}$ & $\begin{array}{c}\mathrm{W} \\
(100)\end{array}$ & $\begin{array}{c}\mathrm{L} \\
(100)\end{array}$ & $\begin{array}{c}\mathrm{M} \\
(100)\end{array}$ & $\begin{array}{c}\mathrm{M} \\
(77.1)\end{array}$ \\
\hline 14324500 & $\begin{array}{l}\text { West Fork Millicoma River } \\
\text { near Allegany, OR }\end{array}$ & $\begin{array}{c}\mathrm{V} \\
(100)\end{array}$ & $\begin{array}{c}\mathrm{W} \\
(100)\end{array}$ & $\begin{array}{c}\mathrm{L} \\
(100)\end{array}$ & $\begin{array}{c}\mathrm{M} \\
(100)\end{array}$ & $\begin{array}{c}\mathrm{M} \\
(100)\end{array}$ \\
\hline 14325000 & $\begin{array}{l}\text { South Fork Coquille River at } \\
\text { Powers, OR }\end{array}$ & $\begin{array}{c}\mathrm{V} \\
(86.3)\end{array}$ & $\begin{array}{c}\mathrm{W} \\
(100)\end{array}$ & $\begin{array}{c}\mathrm{L} \\
(100)\end{array}$ & $\begin{array}{c}\text { M } \\
(100)\end{array}$ & $\begin{array}{c}\text { M } \\
(99.3)\end{array}$ \\
\hline 14328000 & $\begin{array}{l}\text { Rogue River above Prospect, } \\
\text { OR }\end{array}$ & $\begin{array}{c}\mathrm{V} \\
(68.3)\end{array}$ & $\begin{array}{c}\mathrm{s} \\
(71)\end{array}$ & $\begin{array}{c}\mathrm{H} \\
(69.2)\end{array}$ & $\begin{array}{c}\mathrm{M} \\
(99.4)\end{array}$ & $\begin{array}{c}\mathrm{H} \\
(78.9)\end{array}$ \\
\hline 14333500 & $\begin{array}{l}\text { Red Blanket Creek near } \\
\text { Prospect, OR }\end{array}$ & $\begin{array}{c}\mathrm{W} \\
(100)\end{array}$ & $\begin{array}{c}\mathrm{s} \\
(100)\end{array}$ & $\begin{array}{c}\mathrm{H} \\
(100)\end{array}$ & $\begin{array}{c}M \\
(100)\end{array}$ & $\begin{array}{c}\mathrm{H} \\
(100)\end{array}$ \\
\hline 14337800 & $\begin{array}{l}\text { Elk Creek near Cascade } \\
\text { Gorge, OR }\end{array}$ & $\begin{array}{c}\mathrm{W} \\
(100)\end{array}$ & $\begin{array}{c}\mathrm{W} \\
(100)\end{array}$ & $\begin{array}{c}\mathrm{L} \\
(100)\end{array}$ & $\begin{array}{c}\text { M } \\
(99.7)\end{array}$ & $\begin{array}{c}\mathrm{L} \\
(100)\end{array}$ \\
\hline 14337870 & $\begin{array}{l}\text { West Branch Elk Creek near } \\
\text { Trail, OR }\end{array}$ & $\begin{array}{c}\mathrm{W} \\
(100)\end{array}$ & $\begin{array}{c}\mathrm{W} \\
(100)\end{array}$ & $\begin{array}{c}\mathrm{L} \\
(100)\end{array}$ & $\begin{array}{c}\mathrm{M} \\
(100)\end{array}$ & $\begin{array}{c}\mathrm{L} \\
(100)\end{array}$ \\
\hline 14338000 & Elk Creek near Trail, OR & $\begin{array}{c}\mathrm{W} \\
(97.1)\end{array}$ & $\begin{array}{c}\mathrm{W} \\
(100)\end{array}$ & $\begin{array}{c}\mathrm{L} \\
(100)\end{array}$ & $\begin{array}{c}\mathrm{M} \\
(99.8)\end{array}$ & $\begin{array}{c}\mathrm{L} \\
(100)\end{array}$ \\
\hline 14362250 & Star Gulch near Ruch, OR & $\begin{array}{c}\mathrm{M} \\
(100)\end{array}$ & $\begin{array}{c}\mathrm{W} \\
(100)\end{array}$ & $\begin{array}{c}\mathrm{L} \\
(100)\end{array}$ & $\begin{array}{c}\mathrm{M} \\
(100)\end{array}$ & $\begin{array}{c}\mathrm{M} \\
(100)\end{array}$ \\
\hline 14371500 & $\begin{array}{l}\text { Grave Creek at Pease Bridge, } \\
\text { near Placer, OR }\end{array}$ & $\begin{array}{c}\mathrm{W} \\
(100)\end{array}$ & $\begin{array}{l}\mathrm{W} \\
(100)\end{array}$ & $\begin{array}{c}\mathrm{L} \\
(100)\end{array}$ & $\begin{array}{c}M \\
(100)\end{array}$ & $\begin{array}{c}M \\
(100)\end{array}$ \\
\hline 14400000 & $\begin{array}{l}\text { Chetco River near } \\
\text { Brookings, OR }\end{array}$ & $\begin{array}{c}\mathrm{V} \\
(100)\end{array}$ & $\begin{array}{c}\mathrm{W} \\
(100)\end{array}$ & $\begin{array}{c}\mathrm{L} \\
(81.1)\end{array}$ & $\begin{array}{c}\mathrm{M} \\
(100)\end{array}$ & $\begin{array}{c}\mathrm{L} \\
(55.8)\end{array}$ \\
\hline
\end{tabular}

